The Canadian Mineralogist

Vol. 43, pp. 2099-2116 (2005)

\title{
THE NUCLEAR FUEL CYCLE versus THE CARBON CYCLE
}

\author{
RODNEY C. EWING ${ }^{\S}$ \\ Department of Geological Sciences, Department of Materials Science \& Engineering and \\ Department of Nuclear Engineering \& Radiological Sciences, The University of Michigan, C.C. Little Building, \\ 1100 North University Avenue, Ann Arbor, Michigan 48109-1009, USA
}

\begin{abstract}
Nuclear power provides approximately $17 \%$ of the world's electricity, which is equivalent to a reduction in carbon emissions of $\sim 0.5$ gigatonnes $(\mathrm{Gt})$ of $\mathrm{C} / \mathrm{yr}$. This is a modest reduction as compared with global emissions of carbon, $\sim 7 \mathrm{Gt} \mathrm{C} / \mathrm{yr}$. Most analyses suggest that in order to have a significant and timely impact on carbon emissions, carbon-free sources, such as nuclear power, would have to expand total production of energy by factors of three to ten by 2050 . A three-fold increase in nuclear power capacity would result in a projected reduction in carbon emissions of 1 to $2 \mathrm{GtC} / \mathrm{yr}$, depending on the type of carbon-based energy source that is displaced. This three-fold increase utilizing present nuclear technologies would result in 25,000 metric tonnes (t) of spent nuclear fuel (SNF) per year, containing over $200 \mathrm{t}$ of plutonium. This is compared to a present global inventory of approximately $280,000 \mathrm{t}$ of SNF and $>1,700 \mathrm{t}$ of Pu. A nuclear weapon can be fashioned from as little as $5 \mathrm{~kg}$ of ${ }^{239} \mathrm{Pu}$. However, there is considerable technological flexibility in the nuclear fuel cycle. There are three types of nuclear fuel cycles that might be utilized for the increased production of energy: open, closed, or a symbiotic combination of different types of reactor (such as, thermal and fast neutron reactors). The neutron energy spectrum has a significant effect on the fission product yield, and the consumption of long-lived actinides, by fission, is best achieved by fast neutrons. Within each cycle, the volume and composition of the high-level nuclear waste and fissile material depend on the type of nuclear fuel, the amount of burn-up, the extent of radionuclide separation during reprocessing, and the types of materials used to immobilize different radionuclides. As an example, a ${ }^{232} \mathrm{Th}-$ based fuel cycle can be used to breed fissile ${ }^{233} \mathrm{U}$ with minimum production of Pu. In this paper, I will contrast the production of excess carbon in the form of $\mathrm{CO}_{2}$ from fossil fuels with the production of plutonium in a uranium-based nuclear fuel cycle, with special emphasis on the "mineralogical solution" for the "sequestration" of Pu into pyrochlore structure-types.
\end{abstract}

Keywords: nuclear power, nuclear fuel cycle, thorium fuel cycle, carbon cycle, plutonium, uranium, thorium, carbon, global warming, climate change.

\section{SOMMAIRE}

L'énergie nucléaire fournit environ $17 \%$ de l'énergie électrique à l'échelle mondiale, ce qui équivaut à une réduction des émissions de carbone d'environ 0.5 gigatonnes (Gt) par année. Il s'agit d'une réduction plutôt modeste comparée aux émissions globales de carbone, environ $7 \mathrm{Gt} C$ par année. Dans la plupart des analyses, il ressort qu'afin d'avoir un impact marqué et à point sur les émissions de carbone, des sources d'énergie sans carbone, par exemple l'énergie nucléaire, devront fournir une portion accrue de l'énergie totale, selon un facteur de trois à dix avant 2050. Une augmentation selon un facteur de trois mènerait à une réduction prévue des émissions de carbone de 1 à $2 \mathrm{Gt} \mathrm{C}$ par année, dépendant de la nature de la source à base de carbone qui se trouve remplacée. Une telle augmentation par un facteur de trois fois mettant en oeuvre les percées technologiques actuelles dans le domaine nucléaire mènerait à 25,000 tonnes de combustible nucléaire usagé par année, contenant plus de $200 \mathrm{t}$ de plutonium. Ceci compare avec un inventaire global actuel d'environ 280,000 t de combustible nucléaire usagé et plus de 1,700 t de Pu. On peut fabriquer une arme nucléaire avec aussi peu que $5 \mathrm{~kg} \mathrm{de}{ }^{239} \mathrm{Pu}$. Il y a toutefois une flexibilité technologique considérable dans le cycle des combustibles nucléaires. Trois sortes de tels cycles pourraient être utilisés pour une production accrue d'énergie: cycle ouvert, cycle fermé, ou une combinaison symbiotique de différents types de réacteur (par exemple, réacteur thermique et réacteur à neutrons rapides). Le spectre d'énergie neutronique exerce un effet important sur le taux de formation des produits de fission; la consommation d'actinides à longue demi-vie par fission favorise l'utilisation de neutrons rapides. Dans chaque cycle, le volume et la composition des déchets nucléaires fortement radioactifs et des matériaux fissiles dépendent du type de combustible nucléaire, la portée de la combustion nucléaire, le degré de séparation des radionucléides au cours du retraitement du combustible, et la nature des matériaux utilisés pour immobiliser les divers radionucléides. A titre d'exemple, un cycle de combustible nucléaire fondé sur ${ }^{232} \mathrm{Th}$ pourrait servir à produire de l'uranium fissile ${ }^{233} \mathrm{U}$ avec un minimum de Pu produit. Ici,

$\S \quad$ E-mail address: rodewing@umich.edu 
je contraste la production d'un excédent de carbone sous forme de $\mathrm{CO}_{2}$ à partir des sources d'énergie fossiles avec la production de plutonium dans un cycle de combustibles nucléaires fondé sur l'uranium, avec emphase particulière sur la "solution minéralogique" de séquestration du Pu dans des composés du groupe du pyrochlore.

(Traduit par la Rédaction)

Most-clés: énergie nucléaire, cycle de combustibles nucléaires, cycle de combustible à thorium, cycle du carbone, plutonium, uranium, thorium, carbone, réchauffement global, changements climatiques.

\section{INTRODUCTION}

In 2005, the $50^{\text {th }}$ Anniversary of the Mineralogical Association of Canada, one can only pause and say, "What a difference fifty years makes." Since the mid-1950s, two initially very different issues, global warming due to greenhouse gases, mainly $\mathrm{CO}_{2}$ emitted into the atmosphere by the burning of fossil fuels, and the future of nuclear power, $\mathrm{a} \mathrm{CO}_{2}$-free source of energy, have converged into a single discussion. On February $16^{\text {th }}$ of this year, the Kyoto Protocol entered into force, but there is still no clear way forward on the means by which, or the degree to which, carbon emissions may be reduced. A number of countries with rapidly developing economies, such as China, have made a strong commitment to nuclear power. China presently derives nearly $80 \%$ of its electricity from burning coal, but it has embarked on an ambitious nuclear energy program calling for new reactors at a rate of two per year until 2020, projecting an eight-fold increase in electric power generation. There are now many analysts (Ansolabehere et al. 2003, National Commission on Energy Policy 2004) who have evaluated the relation between projected demands for energy and energy sources, particularly decarbonized fossil fuels and nuclear fission. In this paper, I try to highlight some of the aspects of these energy issues that would benefit from active involvement of mineralogists, geochemists and petrologists.

\section{Nuclear Power 50 Years Ago}

The years just prior to 1955 witnessed the beginnings of the nuclear power industry in the United States. Nuclear energy was first used for electrical power generation on December 20th, 1951, in Idaho, when the Experimental Breeder Reactor Number 1 (EBR-1) produced the first electrical power, enough to light four bulbs. In 1953, the United States Navy began tests of pressurized light-water reactors (LWR) for the U.S. submarine fleet, and by 2000 , the U.S. Navy had 73 submarines and nine surface combat ships powered by nuclear reactors. The LWR reactor design, both pressurized water reactors (PWRs) and boiling water reactors (BWRs), became the foundation of the U.S. nuclear power industry, and the first commercial LWR (90 megaWatts of electrical output, MWe) was built at Shippingport, Pennyslvania, and commenced operation at the end of 1957. Lewis Strauss, chairman of the Atomic Energy Commission (AEC) in the 1950s, expressed the view that nuclear energy would be "... too cheap to meter...", and in 2005 , there are 103 operating nuclear reactors in the United States with a total capacity of approximately $100 \mathrm{GWe}$, producing nearly $20 \%$ of the electricity in the United States. Worldwide, 433 nuclear power reactors in 31 countries have a total capacity of $350 \mathrm{GW}$, accounting for $17 \%$ of the electricity produced. These nuclear reactors have also generated over 280,000 metric tonnes of highly radioactive spent nuclear fuel (SNF), slightly less than $20 \%$ of this amount is in the United States, awaiting the submission and approval of a license for the disposal of SNF and high-level waste (HLW) at the Yucca Mountain site in Nevada. Over eight billion \$US have been spent over the past two decades on the Yucca Mountain site in order to dispose of the wastes from this "... too cheap to meter ..." source of energy.

Intricately tied to the development of nuclear power has been the development and proliferation of nuclear weapons. In the midst of the Cold War, the former Soviet Union created the Warsaw Pact in 1955, as a response to the North Atlantic Treaty Organization. Both sides had been pursuing programs of nuclear weapons development and testing, and by 1955 , there were already approximately 3,000 nuclear weapons held by three countries (United States, USSR and the United Kingdom). The number of nuclear weapons would peak at over 70,000 by 1986 . These nuclear weapons programs have left a huge legacy of nuclear wastes. In the United States, there are approximately $380,000 \mathrm{~m}^{3}$ (100 million gallons) of high-level nuclear waste with a total radioactivity of 960 megaCuries (MCi) that have resulted from the reprocessing of spent nuclear fuel in order to reclaim fissile material (mainly ${ }^{235} \mathrm{U}$ and ${ }^{239} \mathrm{Pu}$ ) for the production of nuclear weapons. Most of these HLW $\left(340,000 \mathrm{~m}^{3}\right)$ are stored in huge tanks at Hanford, Washington, and Savannah River, South Carolina. Fifty-years later, the Soviet Union no longer exists, and former Warsaw Pact states, such as the Czech Republic, Hungary and Poland, have joined NATO. Under the first and second Strategic Arms Reduction Treaties, as well as unilateral pledges made by the USA and Russia, thousands of nuclear weapons are being dismantled. Initially, this disarmament process will produce between 30 to $40 \mathrm{t}$, pure and impure, of weapons-grade plutonium in each country, as well as hundreds of tonnes of highly enriched ${ }^{235} \mathrm{U}$ (HEU). Although the number of nuclear weapons is decreasing, the number of "offi- 
cial" nuclear-weapon states, since 1955, has increased to include France, China, India and Pakistan. Others (Israel, North Korea, and Iran) are believed to have or be seeking nuclear weapon capability.

\section{The Carbon Cycle 50 Years Ago}

In 1955, Hans Suess at Scripps Institution of Oceanography announced that he had detected "ancient" carbon, depleted in ${ }^{14} \mathrm{C}$, which had been added to the modern atmosphere, probably as a result of burning fossil fuels (Suess 1955). In that same year, Suess began his collaboration with Roger Revelle to investigate the fate of carbon in the oceans. Within two years, in their joint paper, Revelle \& Seuss (1957) noted that the accumulation of $\mathrm{CO}_{2}$ may be significant during future decades as the use of fossil fuels would continue to increase. Inspired by these early findings and the possibility of global increases in the $\mathrm{CO}_{2}$ content of the atmosphere, the International Geophysical Year of 1957 provided the initial funding that allowed the first precise measurements of atmospheric $\mathrm{CO}_{2}$ over time at observation posts in Antarctica and on Mauna Loa. The now-famous "Keeling curve" for data from Mauna Loa revealed the inexorable increase of atmospheric $\mathrm{CO}_{2}$ from $315 \mathrm{ppm}$ in 1958 to over $365 \mathrm{ppm}$ at present. The combustion of fossil fuels currently emits some 7 gigatonnes of carbon per year $(\mathrm{GtC} / \mathrm{yr})$ into the atmosphere. Based on the "business-as-usual" scenario of the Intergovernmental Panel on Climate Change, this emission rate will grow to some $19.8 \mathrm{GtC} / \mathrm{yr}$ in 2100 . This is equivalent to an increase from the present 365 ppm $\mathrm{CO}_{2}$ in the atmosphere to $700 \mathrm{ppm} \mathrm{CO}_{2}$ in 2100. To place these numbers in perspective, in order to stabilize $\mathrm{CO}_{2}$ concentrations at twice pre-industrial levels, i.e., $550 \mathrm{ppm}$, cumulative emissions during the next 100 years would have to be reduced by more than $500 \mathrm{GtC}$, as compared with the "business-as-usual" scenario. New or alternative systems of energy would then have to emit no more than $5 \mathrm{GtC} / \mathrm{yr}$. To stabilize $\mathrm{CO}_{2}$ at 450 ppm, all energy production systems must be limited to emitting no more than $3 \mathrm{GtC} / \mathrm{yr}$.

\section{Plutonium Versus CARBon}

Although one may make optimistic assumptions about the potential for technological innovations in energy systems and conservation to substantially mitigate the global impact of energy production, the immediate requirement is for solutions that can be put into place during the next fifty years, limiting the increase in atmospheric $\mathrm{CO}_{2}$ concentrations to twice (550 parts per million) that of pre-industrial levels (275 ppm). At present, the alternatives to fossil fuels for major energyproduction are limited to five possibilities: nuclear fission, biomass, solar, wind, and decarbonized fossil fuels (i.e., the production of $\mathrm{H}$ from hydrocarbons) from which the carbon is sequestered (Fetter 2000).
Unfortunately, no single source of energy is a "silver bullet". Each technology draws on a resource, each requires improvements in the implementing technologies, and all have multiple environmental impacts. Of these five, only the nuclear "option" is presently deployed on a large scale, producing $17 \%$ of the world's electricity. Because nuclear power is so broadly used (in more than 30 countries), there is a substantial basis for evaluating its cost and impact (Ewing 2004). There have been many classic (Budnitz \& Holdren 1976, Pigford 1976) and recent (Ansolabehere et al. 2003, National Commission on Energy Policy 2004) analyses of different energy-producing systems and their impacts. These studies are typically "holistic" in the sense that they consider, not only the technological options, but also economic cost and multiple environmental impacts. In the case of nuclear power, such an analysis is difficult because there are different types of nuclear reactors, and there is not a single nuclear fuel cycle, but rather many variants of "closed" and "open" fuel cycles with different strategies for reprocessing and disposal of nuclear wastes. Another difficulty with these analyses is that they are complex, and their conclusions are generally assumption-driven by the projected growth in population, per capita energy consumption, estimated costs, and estimates of resource reserves.

In this paper, I want to reduce the complexity of the analysis to a simple consideration of the major impacts of nuclear power versus hydrocarbon-based fuels. On one hand, the world has an abundant hydrocarbon-based energy resource for which a principal environmental impact is the increased $\mathrm{CO}_{2}$ content of the atmosphere and global warming. Whether this carbon is emitted into the atmosphere or scrubbed from power plant emissions and "sequestered", society will have to deal with huge volumes of carbon. On the other hand, the world has energy production by nuclear fission, in which the main impact is the production of nuclear waste and fissile material with the potential for the diversion of fissile material to nuclear weapons. Although the enrichment of ${ }^{235} \mathrm{U}$ is an important issue in nuclear weapons proliferation (China took this pathway for its first nuclear weapons), the fate of ${ }^{235} \mathrm{U}$ is not considered in this paper because the enrichment of ${ }^{235} \mathrm{U}$ does not require that a country have a nuclear reactor. In contrast, the production of fissile ${ }^{239} \mathrm{Pu}$ is a unique result of nuclear power production, based on a $\mathrm{U}-\mathrm{Pu}$ fuel cycle. Thus the issues related to nuclear power extend beyond the production of energy by fission, but also require the parallel analyses of the potential of the nuclear fuel cycle to impact on the carbon cycle (e.g., reduce carbon emissions by substituting nuclear power for hydrocarbon-based sources of energy) and the effect of an active, growing nuclear-power industry on the production of nuclear waste and potential for the proliferation of nuclear weapons. The ideal nuclear fuel cycle produces a maximum amount of energy, substantially reduces carbon emissions, provides for the 
safe disposal of nuclear waste, and securely safeguards against the proliferation of nuclear weapons. For this discussion, I do not consider the economics of each of the energy-producing systems or their myriad other environmental impacts. As an example, for fossil fuels, I do not consider the health effects associated with coal mining or the impact of other greenhouse gases as agents of global warming. For nuclear power, I do not consider the issues of accidents at nuclear power plants or nuclear waste disposal. For the latter, there is a general worldwide consensus that geological disposal is the appropriate and safe solution to nuclear waste (National Research Council, 2001); however, one must acknowledge that after considerable effort, there is no geological repository presently accepting spent nuclear fuel or HLW.

Thus, in the very simple analysis in this paper, the question is whether one would prefer to deal with excess carbon or excess plutonium from an energy-producing system. For both carbon and plutonium, energy-producing systems can be optimized to reduce the amount of these elements produced; however, reactors also have the possibility of transmuting actinides. For carbon sequestration, the possibilities include oceanic, terrestrial, geological disposal options or some that are transformational. Geological methods involve injection into active or depleted oil and gas fields, saline aquifers and deep coal beds. The terrestrial solutions involve biomass production and carbon fixation in soils. Transformational approaches convert the $\mathrm{CO}_{2}$ to solids or liquids that can be disposed of without adverse environmental impacts. Regardless of the approach, the volumes of material to be handled are huge, and the half-life of the dominant isotope, ${ }^{12} \mathrm{C}$, is essentially infinite. For ${ }^{239} \mathrm{Pu}$, a similar option is available, that is, incorporation into solids that are chemically durable and radiation-resistant, combined with disposal in geological environments that result in long-term containment. The volumes of plutonium are relatively small (thousands of metric tonnes), and the half-life is relatively short (24,100 years). For plutonium, there is the additional possibility of "burning" plutonium and other actinides in a fast neutron flux (Pigford 1990); however, such an approach requires reprocessing of spent nuclear fuel with the associated environmental impact and the possibility of proliferation of nuclear weapons.

\section{The NuClear Fuel CyCle}

Since plutonium was isolated in microgram quantities in February of 1941 by G.T. Seaborg, J.W. Kennedy and A.C. Wahl, more than 1,700 metric tonnes (t) of plutonium have been created in nuclear reactors around the world. Approximately $300 \mathrm{t}$ are held in weapons programs, more than $200 \mathrm{t}$ have been separated from commercially generated spent nuclear fuel, mostly in the United Kingdom and France, and the balance, over $1,200 \mathrm{t}$, remains in spent nuclear fuel stored on-site at 236 nuclear power plants in 36 different countries (Albright et al. 1997, Carter \& Pigford 1999). Approximately 70 to $80 \mathrm{t}$ of new plutonium, generally left in the spent nuclear fuel, is added to the global inventory each year. Reactor-grade plutonium $\left(>60 \%{ }^{239} \mathrm{Pu}\right)$ with any degree of irradiation is a potential weapons material, and a nuclear device can be made with less than $10 \mathrm{~kg}$ of ${ }^{239} \mathrm{Pu}$ (Mark 1993).

The different fuel cycles reflect different strategies for the utilization of fissile nuclides, mainly ${ }^{235} U$ and ${ }^{239} \mathrm{Pu}$, and these different strategies have important implications for nuclear waste management and nuclear weapons proliferation. The "once-through" open-cycle (Fig. 1) treats the spent fuel as a waste without any attempt to reclaim the remaining ${ }^{235} \mathrm{U}$ or newly created ${ }^{239} \mathrm{Pu}$, and the spent nuclear fuel (SNF) is directly disposed of in a geological repository. This is the strategy of the United States. A closed-fuel cycle (Fig. 2) with reprocessing retrieves approximately $99 \%$ of the fissile nuclides. However, the recovered fissile nuclides are only a supplement to the nuclear fuel that is mainly derived from newly mined ore. In this case, the highlevel waste from reprocessing and the unprocessed SNF are disposed of in a geological repository. The breederreactor cycle creates more fissile material in the SNF than in the original fuel, and it involves multiple cycles of reprocessing. In 1977, President Carter decided to indefinitely defer reprocessing of spent nuclear fuel in the United States in order to have a more proliferationresistant fuel cycle. In 1981, President Reagan lifted the ban on reprocessing, but he placed the financial responsibility for reprocessing on the private sector. By the mid-1980s, the commercial reprocessing of SNF had little attraction from a technical, economic, regulatory or policy perspective (Carter 1987). A recent, detailed analysis of the cost of reprocessing, Bunn et al. (2003) suggested that there is no financial incentive to pursue reprocessing, as compared with the simpler strategy of direct disposal of SNF.

In terms of assessing the environmental impact, the type of fuel cycle is probably the most important aspect of nuclear power generation. Reprocessing of the used nuclear fuel is always complicated by the issue of the possible diversion of fissile material and the proliferation of nuclear weapons. The type of fuel cycle is closely tied to the type of nuclear fuel [e.g., low-enrichment uranium (LEU), high-enrichment uranium (HEU), a mixed-oxide (MOX) of $\mathrm{U}+\mathrm{Pu}$, or an inert matrix fuel (IMF) in which the matrix is not fertile (e.g., $\mathrm{ZrO}_{2}$, and does not breed additional $\mathrm{Pu}$ ), the degree of burn-up (e.g., at lower burn-up the inventory of $\mathrm{Pu}$ is higher), and the types of solids used for the immobilization of the waste (e.g., separate waste-forms for actinides and fission products]. To the extent that the choice between fuel cycles is driven by economic considerations, an open fuel-cycle prevails as long as the price of uranium is lower than the cost of reprocessing (von Hippel 2001, Bunn et al. 2003). Thus, there 


\section{Open Nuclear Fuel Cycle}

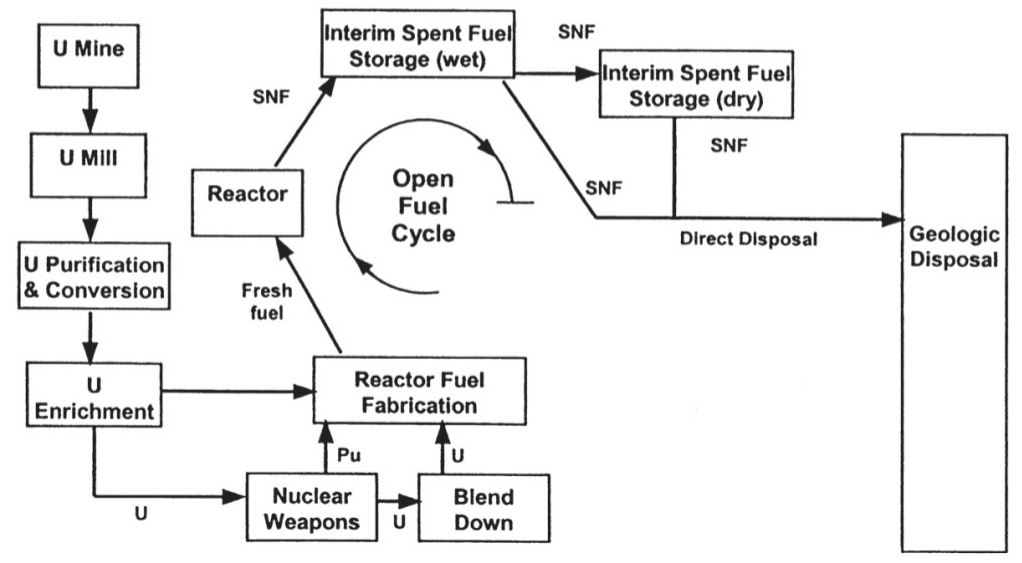

FIG. 1. Schematic illustration of the ideal open nuclear-fuel cycle (National Research Council 2003). In this case, there is no reprocessing. The spent fuel still contains fissile nuclides, such as ${ }^{235} \mathrm{U}$ and ${ }^{239} \mathrm{Pu}$ (generated by neutron-capture reactions on ${ }^{238} \mathrm{U}$ ). Reprinted with permission from End Points for Spent Nuclear Fuel and High-Level Radioactive Waste in Russia and the United States (2003) by the National Academy of Sciences. Courtesy of the National Academies Press, Washington, D.C.

are no simple criteria that can serve as a basis for the selection of a fuel cycle, as environmental, proliferation, and economic issues are closely tied to a nation's energy policy, and that depends on the energy resources that are available to each country.

A recent MIT study has compared generic fuelcycles for a global growth scenario that is based on an expansion of the worldwide capacity for nuclear power generation by a factor of three $(1,000 \mathrm{GW})$ by the year 2050 (Ansolabehere et al. 2003). This would result in avoiding $1.8 \mathrm{GtC}$ (if the displacement is from coal-burning plants), which is approximately $25 \%$ of the annual global emissions (Houghton 2000, Houghton et al. 2001). The MIT study considered three fuel cycles: 1) a once-through cycle with direct geological disposal of the SNF (at different burn-ups), 2) a single cycle of reprocessing in which the plutonium is fabricated into a MOX fuel, and 3) a fully closed fuel cycle with a "symbiotic" combination of thermal and fast reactors, the latter used to burn separated actinides (Fig. 3). An important aspect of the third type of fuel cycle is whether there is repeated reprocessing of the SNF from the thermal reactors, or whether repeated cycles of reprocessing are limited to the fast reactors. The general characteristics of each of these fuel cycles are summarized in Table 1. Although the data in Table 1 provide a very simplified view of the attributes of the different fuel-cycles, one can see immediately that there are important differences in the volumes and types of radioactive waste generated. The once-through cycle followed by direct geological disposal generates the largest volumes of SNF that contains substantial quantities of $\mathrm{Pu}$ (which can be viewed as either a source of energy or an environmental hazard). Going to higher burn-up reduces the volume of SNF generated per unit of energy and reduces, by approximately $100 \mathrm{t}$, the $\mathrm{Pu}$ in the spent fuel, because the fissioning of ${ }^{239} \mathrm{Pu}$ accounts for nearly one-third of the energy generated in a typical LWR $\left[{ }^{239} \mathrm{Pu}\right.$ is created by $(\mathrm{n}, \gamma)$ reactions on $\left.{ }^{238} \mathrm{U}\right]$. The proliferation risks are minimized because there is no separated $\mathrm{Pu}$. The $\mathrm{Pu}$ in the SNF is protected from diversion by the strong field of radiation generated by the fission products in the SNF. The closed fuel-cycle (the MOX option with one recycle) has the advantage of more efficient use of the fissile radionuclides $\left({ }^{235} \mathrm{U}\right.$ and ${ }^{239} \mathrm{Pu}$ ), which are fabricated into MOX fuel. However, of the total amount of $\mathrm{Pu}(233 \mathrm{t})$ discharged in the spent uranium oxide (UOX) fuel, $167 \mathrm{t}$ of the $\mathrm{Pu}$ will be separated. This amount of separated plutonium is equivalent to thousands of nuclear weapons. For both the open and closed fuel-cycles, uranium, as well as Th-based fuels, may be utilized in different types of reactors, such as heavy-water reactors (HWR), supercritical-water reactors (SCRW), and high-temperature and very-high- 


\section{Closed Nuclear Fuel Cycle}

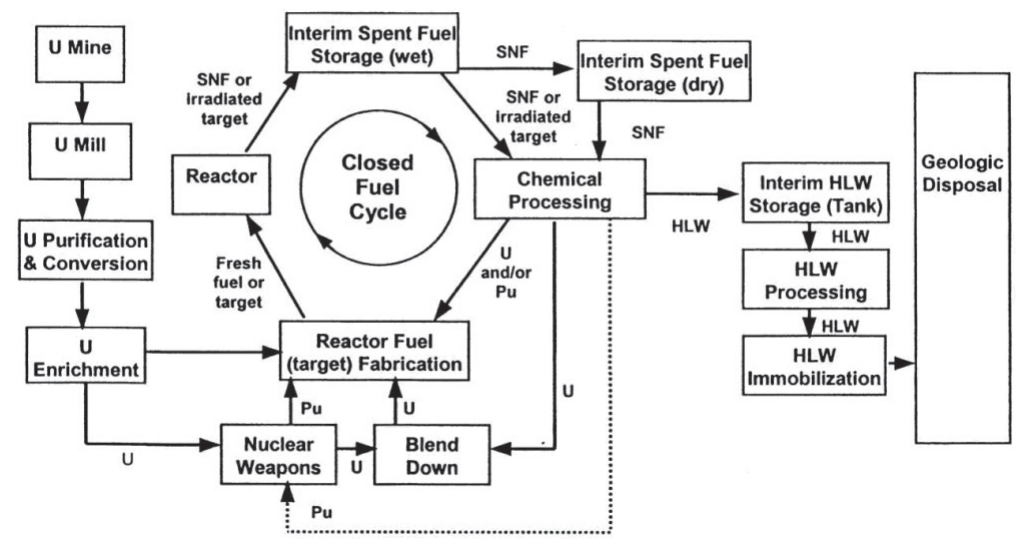

FIG. 2. Schematic illustration of the ideal closed nuclear-fuel cycle (National Research Council 2003). In practice, the reprocessing capacity does not match the generation rate of the spent nuclear fuel; thus, the excess SNF must be placed in interim storage or disposed of in a geological repository. Under normal circumstances, the SNF will be in interim storage for just a few years. Also, note that excess material from nuclear weapons, e.g., highly enriched ${ }^{235} \mathrm{U}$ and ${ }^{239} \mathrm{Pu}$, can be blended down and used as a reactor fuel. Reprinted with permission from End Points for Spent Nuclear Fuel and High-Level Radioactive Waste in Russia and the United States (2003) by the National Academy of Sciences. Courtesy of the National Academies Press, Washington, D.C.

temperature gas-cooled reactors (HTGR). However, the introduction of new fuels, new reactors, and advanced fuel-cycles will require considerable resources and experience prior to deployment. The fully closed fuelcycle is one in which the actinides are separated from the spent fuel of the thermal reactors (once-through cycle) and incorporated into MOX fuel and burned in the fast neutron reactors. The fast-neutron flux transmutes the actinides, and multiple cycles of reprocessing are used for the fast reactor fuel. This strategy significantly reduces the inventories of plutonium and minor actinides, transmuting the actinides to shorter-lived radionuclides. In this scheme, the production of the actinides in thermal reactors fuel must be carefully balanced with burning them in recycled MOX. Because MOX fuel consists mainly of ${ }^{238} \mathrm{U}$, additional ${ }^{239} \mathrm{Pu}$ is created by neutron capture and subsequent $\gamma$-decay reactions. The amount of $\mathrm{Pu}$ created can be reduced by burning the actinides in an inert-matrix fuel (IMF), i.e., one that does not contain fertile ${ }^{238} \mathrm{U}$ (e.g., $\mathrm{ZrO}_{2}$ ), which will provide more efficient burning of the actinides (Boczar et al. 1997, Oversby et al. 1997). In this case, reactors would burn a mixture of MOX and IMF (perhaps up to one-third of the core loading). This option substantially reduces the $\mathrm{Pu}$ and minor actinide content of irradiated $\mathrm{IMF}$, and the zirconia $\left(\mathrm{ZrO}_{2}\right)$ is recognized as a durable, radiation-resistant waste form for direct disposal (Gong et al. 2000). The use of $\mathrm{ZrO}_{2}$ as an inert matrix fuel is under active investigation in Europe and Japan, but it may take more than a decade to confirm its behavior under actual operating conditions in a reactor. This fully closed fuel-cycle should not be confused with breeder reactor fuel-cycles, in which breeder fast reactors are used to generate $\mathrm{Pu}$, which is then burned as MOX fuel in thermal reactors. In the latter sequence, the inventory of $\mathrm{Pu}$ will increase.

During the past decade, a new type of waste has emerged, the plutonium from dismantled nuclear weapons. Under the first and second Strategic Arms Reduction Treaties, as well as unilateral pledges made by the USA and Russia, thousands of nuclear weapons will be dismantled. Initially, this disarmament process will produce between 30 to $40 \mathrm{t}$ of pure and impure weapons-grade plutonium in each country, as well as hundreds of tonnes of highly enriched ${ }^{235} \mathrm{U}$ (HEU). Still, this will leave well over $200 \mathrm{t}$ of separated plutonium in nuclear weapons. In September 2000, the USA and Russia signed a Plutonium Management and Disposition Agreement that commits each country to dispose of $34 \mathrm{t}$ of surplus $\mathrm{Pu}$. Russia plans to fabricate a MOX fuel with the $\mathrm{Pu}$ and use it in existing or future reactors as part of its larger strategy to close the fuel cycle. The 
United States will also fabricate a MOX fuel to be used in existing commercial reactors, but there is presently no strategy for the fate of 5 to $7 \mathrm{t}$ of so-called "scrap" plutonium that is too contaminated with impurities to be used in a MOX fuel.

An equally important problem is the fate of plutonium separated from commercially generated nuclear fuel originally destined for fabrication as a MOX (U + $\mathrm{Pu})$ fuel. The largest inventories are in France $(72 \mathrm{t}$, of which $33.6 \mathrm{t}$ is foreign owned) and Great Britain (60 $\mathrm{t}$, of which $6.1 \mathrm{t}$ is foreign owned). The USA has only $5 \mathrm{t}$ of this so-called "civil" plutonium. Japan has $5 \mathrm{t}$ of $\mathrm{Pu}$, but it has another $24.1 \mathrm{t}$ held in other countries, mainly France (Albright et al. 1997). Global inventories at the end of 2002 of this separated civil Pu were over 230 t (Albright \& Kramer 2004), but it is now clear that not all of it will be fabricated into a MOX fuel (Ewing 2001). France has approximately $200 \mathrm{t}$ of civil Pu already fabricated into MOX fuel for its 20 LWRs, but the inventory of civil plutonium continues to grow. This is an extremely important proliferation and environmental problem, as the bare critical mass of ${ }^{239} \mathrm{Pu}$ is less than $10 \mathrm{~kg}$ (Mark 1993), and such small volumes could be diverted to the production of a nuclear weapon. In addition, $\mathrm{Pu}$ can cause acute health effects (Sutcliffe et al. 1995), and although these effects are often exaggerated in the press, this is inevitably a major public health concern.

One of the most active areas of research during the past decade has been the search for durable, solid matrices for the immobilization of $\mathrm{Pu}$ and other actinides (Ewing 2001, Ewing et al. 2004a). Of equal importance are the stockpiles of highly enriched ${ }^{235} \mathrm{U}$ (HEU): 645 t (USA) and 1,050 t (Russia) (Bunn \& Holdren 1997). The HEU can be blended down to lowenrichment uranium (LEU) $\left(4 \%{ }^{235} \mathrm{U}\right)$ for use in LWRs. In 1993, the United States agreed to purchase $500 \mathrm{t}$ of Russian weapons-origin uranium that was then blended down to low-enrichment uranium (LEU) for use in commercial reactors. As of 2003, $193 \mathrm{t}$ of bomb-grade HEU have been converted to 5,700 t LEU for fuel in nuclear power plants (NPP). The HEU could have been used to produce over 7,700 nuclear weapons.

\section{Nuclear Power and Reduced CARbon Emissions}

In 1997, the third Conference of the Parties (COP-3) produced the Kyoto Protocol. Although signed by then Vice-President Al Gore, it has not been ratified by the Senate of the USA. To enter into force, the Protocol must be ratified by 55 parties representing at least $55 \%$ of the world's emissions of greenhouse gases (GHG) in 1990. The Kyoto Protocol entered into force on February 16, 2005, after ratification by Russia. As part of the Protocol, the developed countries must commit themselves to reducing their collective emissions of six GHG to at least 5\% below 1990 levels. The most prominent of these GHG is $\mathrm{CO}_{2}$, which accounts for nearly $65 \%$ of the warming effect (Houghton et al. 2001). The USA presently accounts for approximately $25 \%$ of the global emissions of $\mathrm{CO}_{2}$ with $5 \%$ of the world's population. The Kyoto Protocol would require the USA to reduce emissions by $7 \%$ below 1990 levels, an annual reduction of $1.1 \times 10^{9} \mathrm{t} \mathrm{CO}_{2}$, equivalent to removing all the gasoline-powered vehicles from U.S. roads (Loewen \& León 2001). The USA produces nearly $20 \%$ of its electricity using nuclear power, and this is equivalent to avoiding the release of $6 \times 10^{8} \mathrm{t}$ $\mathrm{CO}_{2}$, if this electricity had been produced from carbonbased fuels (Loewen \& León 2001).

There is a pressing need to develop a timely strategy to reduce GHG emissions. Thus, a number of analyses are based on a goal of limiting the increase in $\mathrm{CO}_{2}$ emissions to twice (550 ppm) the pre-industrial levels (275 ppm) by the year 2050 (Fetter 2000, Sailor et al.

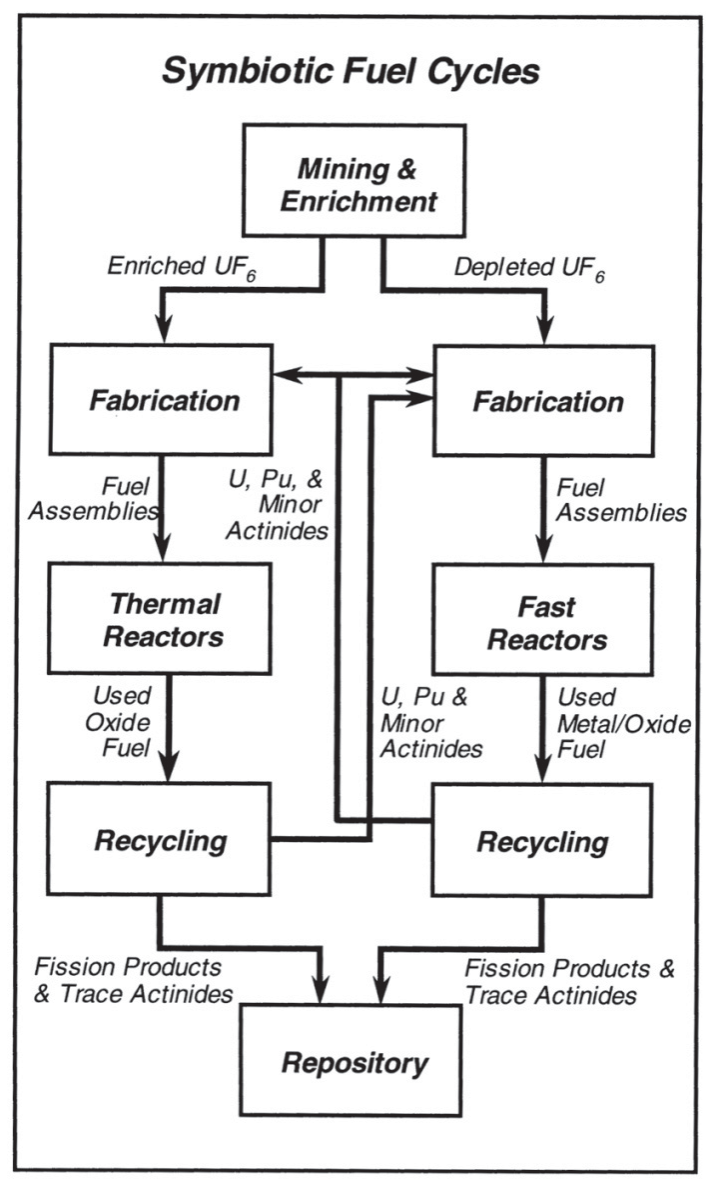

FIG. 3. Schematic illustration of a "symbiotic" nuclear-fuel cycle that utilizes both thermal and fast reactors. The fast reactors are used to "burn" long-lived actinides (Department of Energy 2002). 
TABLE 1. SELECTED CH $\Lambda$ R $\Lambda$ CTERISTICS OF GENERIC FUEL-CYCLES BASED ON A PROJFCTED DEPLOYMENT OF 1500 GWe (GIGAWATTS OF ELECTRICITY) PER YEAR IN THE 2050

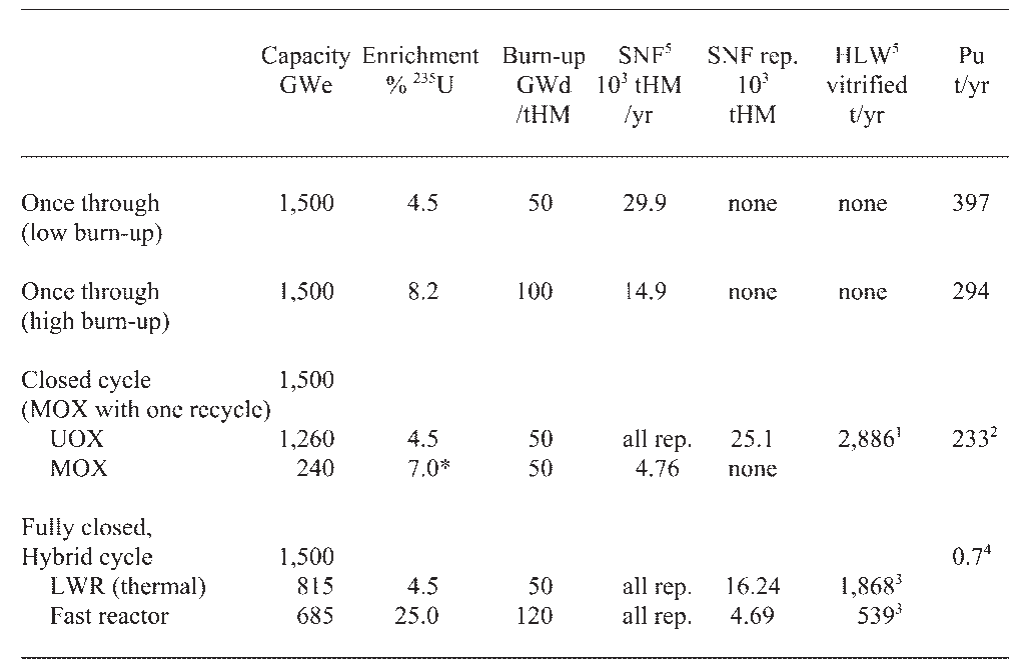

1 The borosilicate glass contains $1292.6 \mathrm{t} / \mathrm{yr}$ of fission products, $30.1 \mathrm{t} / \mathrm{yr}$ of minor actinides, and $0.3 \mathrm{t} / \mathrm{yr}$ of $\mathrm{Pu}$. Symbols: $\mathrm{t}$ : metric tonne, tHM: tonnes of heavy metal, GWd: gigawatts - day

${ }^{2}$ Of the 2331 of $\mathrm{Pu}$ that are generated, $167 \mathrm{t}$ of separated $\mathrm{Pu}$ are incorporated into MOX fuel; their processing also generates $23,443 \mathrm{t} / \mathrm{yr}$ of separated uranium.

${ }^{3}$ Mass of borosilicate glass estimated by the author. This borosilicate glass contains $48.6 \mathrm{t} / \mathrm{yr}$ of fission products, $1.1 \mathrm{t} / \mathrm{yr}$ of plutonium and minor actinides.

${ }^{4}$ Lost during reprocessing.

${ }^{5}$ SNF: spent nuclear fuel. ILWW: high-level waste, rep.: reprocessed. * Pu in MOX.

These figures are taken from Ansolabehere et al. (2003). The details of the calculations are very important and are given in the appendix of their study.

2000). Present levels of $\mathrm{CO}_{2}$ are just over $360 \mathrm{ppm}$, increasing at an average rate of $1.5 \mathrm{ppm} / \mathrm{yr}$. This adds $3.3 \mathrm{GtC} / \mathrm{yr}$ to the atmospheric reservoir, which is 750 $\mathrm{GtC}$ (Houghton et al. 2001). Models of $\mathrm{CO}_{2}$ emissions suggest that strategies for reduction must be initiated in developed countries by 2010 in order to meet the goal of only doubling of the $\mathrm{CO}_{2}$ concentration above the pre-industrial level (Wigley 1997). As previously discussed, of all of the technologies presently capable of contributing to a major reduction in carbon emissions, nuclear power is one of the most promising, simply because the technology is already operating on a substantial scale, and in principle, it could be deployed more rapidly on a global scale. The Nuclear Energy Institute (NEI) maintains that the USA capacity for nuclear power generation can be increased by $10 \mathrm{GW}$ by 2012 (equivalent to a reduction of $0.022 \mathrm{GtC} / \mathrm{yr}$ ). The NEI supports a goal of adding 50 GW capacity (= approximately 50 new NPP) by 2020 (equivalent to a reduction of $0.1 \mathrm{GtC} / \mathrm{yr}$ ).

Analyses of the prospects of nuclear power have been presented by many, but two of the most detailed are by Fetter (2000) and Sailor et al. (2000). Authors of these analyses necessarily make many assumptions about future energy needs. Assuming a stabilization of $\mathrm{CO}_{2}$ concentrations to approximately twice preindustrial levels by 2050 , and projecting a growth in world population to 9 billion (a 50\% increase) and an increase in per capita energy consumption of $50 \%$, the global energy demand in 2050 will be approximately 900 exajoules $\left(10^{18}\right.$ joules $)$ per year $(\mathrm{EJ} / \mathrm{yr})$ (Sailor et al. 2000). If nuclear power provides one-third of the projected energy requirement $(300 \mathrm{EJ} / \mathrm{yr})$, and the balance is divided equally between conventional fossil fuels and "decarbonized" fossil fuels, the 300 EJ from nuclear power are roughly equivalent to $3300 \mathrm{GW}$-years (one GWyr is the average annual energy output from a single large power plant) of capacity per year (present capacities are about $260 \mathrm{GWyr} / \mathrm{yr}$ ). With this scenario, the projected $900 \mathrm{EJ} / \mathrm{yr}$ of global energy use would still result in $\mathrm{CO}_{2}$ emissions that would equal $5.5 \mathrm{GtC} / \mathrm{yr}$ (present levels are $\sim 7 \mathrm{GtC} / \mathrm{yr}$ ) (Sailor et al. 2000). Still, this would mean more than a ten-fold increase in nuclear power generation capacity, requiring the construction of over 3,000 NPP before 2050 (at present there are 439 operating nuclear generating units). The 
impact of this expansion in nuclear-power-generation capacity is difficult to anticipate because it depends critically on the types of reactors and fuel cycles that are used, as previously discussed. The figures previously cited from the MIT study (Ansolabehere et al. 2003) and tabulated in Table 1 are based on an increase by a factor of three of nuclear-power-generation capacity by $2050(1,000 \mathrm{GW})$. Still, one must expect that the most immediate deployment of new reactors will be of the Generation III+ type, not too different from the present water-reactor technology, but with higher burn-up of the nuclear fuel. Thus, one may use the present technology as a basis for extrapolating the environmental impact and use the factors of 3 to 10 as the range of what has been considered for the increase in nuclear power production. On this basis, the annual increase in global spent-fuel production would be between 27,000 and 89,000 metric tonnes of heavy metal (tHM). The higher number is greater than the presently planned capacity $(70,000$ tHM equivalent) for the proposed repository at Yucca Mountain. One approach to reducing the impact of the increased production of nuclear waste is to use reprocessing to minimize the volumes of waste produced and to utilize the fissile content of the SNF; however, this raises major issues related to the proliferation of nuclear weapons. A one-GWyr light water reactor produces $200 \mathrm{~kg} / \mathrm{yr}$ of $\mathrm{Pu}$ (enough for 20 nuclear weapons). If the global nuclear-energy capacity is increased to $3,000 \mathrm{GW}$, then the annual production of $\mathrm{Pu}$ would be over $500,000 \mathrm{~kg}$ (Williams \& Feiveson 1990). If one foresees a nuclear industry based on $\mathrm{Pu}-$ breeder reactors, the $3,000 \mathrm{GW}$ nuclear system would produce five million kilograms of plutonium per year (Williams \& Feiveson 1990). Alvin Weinberg (2000) has related the reduction (avoided increase) in $\mathrm{CO}_{2}$ content in the atmosphere to the amount of $\mathrm{U}$ consumed, that is the percentage of $U$ fissioned in nuclear power plants. A typical LWR without reprocessing has an efficiency (\% of U fissioned) of only $0.5 \%$, whereas a perfect breeder-reactor cycle with reprocessing has an efficiency of $70 \%$. Even if the presently estimated reserves for uranium $\left(30 \times 10^{6} \mathrm{t}\right)$ are completely utilized (Weinberg 2000), the low-efficiency system now in use, LWR followed by direct disposal, will lower the $\mathrm{CO}_{2}$ increase by only $38 \mathrm{ppm}$. Either there will have to be a shift to breeder reactors and reprocessing, or alternative sources of $U$ must be found. All of these figures are speculative, but they do emphasize that an increase in the role of nuclear power in reducing carbon emissions must be substantial and go hand-in-hand with the development of advanced fuel-cycles and wastemanagement technologies that do not presently exist on an industrial scale.

Just as important as evaluating the potential impact of the nuclear fuel cycle on carbon emissions, one must also consider the size of the fluxes and reservoirs of the carbon cycle. Present $\mathrm{CO}_{2}$ emissions from fossil fuels and the production of cement are estimated to be 6.3 $\pm 0.4 \mathrm{GtC} / \mathrm{yr}$; emissions related to changes in land use (e.g., deforestation) are $1.6 \pm 0.8 \mathrm{GtC} / \mathrm{yr}$ (Schimel et al. 2001). At present, the reduction of $\mathrm{CO}_{2}$ emissions that can be attributed to the use of nuclear power is 0.5 $\mathrm{GtC} / \mathrm{yr}$. Thus, the uncertainties in the major fluxes in the carbon cycle are approximately the same as the present impact of nuclear power on $\mathrm{CO}_{2}$ emissions (Sarmiento \& Gruber 2002). To quote Falkowski et al. (2000), "Our knowledge is insufficient to describe the interactions between the components of the Earth system and the relationship between the carbon cycle and other biogeochemical and climatological processes." Thus policy makers will need a much more refined understanding of the carbon cycle and a more explicit description of the nuclear fuel cycle before they can quantify the impact of the nuclear fuel cycle on the carbon cycle.

\section{Mineralogical Solutions}

Depending on one's perspective, plutonium is either a valuable resource to be generated and used in a closed fuel-cycle or a serious threat, contributing to the global proliferation of nuclear weapons. In a study by the National Research Council (1994), the "excess" plutonium from dismantled nuclear weapons was described as ". . . a clear and present danger to national and international security."

\section{Plutonium sequestration}

In the broadest sense, there are two strategies for the disposition of Pu (National Research Council 1994, Bunn \& Holdren 1997, Stoll 1998): 1) The use of nuclear reactors or accelerators to "burn" or reduce the inventories of plutonium and the minor actinides. This strategy involves reprocessing nuclear fuels to reclaim fissile nuclides or the use of $\mathrm{Pu}$ from dismantled nuclear weapons for the fabrication of a mixed oxide (MOX) fuel, consisting of $\mathrm{U}$ and $\mathrm{Pu}$, or the incorporation of fissile and non-fissile actinides into an inert matrix fuel (IMF). Inert matrix fuels do not contain fertile nuclides, such as ${ }^{238} \mathrm{U}$, that lead to the production of more Pu. After a once-through burn-up, the MOX or IMF used fuels would be sent to a geological repository. 2) Direct disposal of spent nuclear fuel or actinidebearing nuclear waste forms in a geological repository. In the 1990s, the United States pursued a dual-track strategy in which the higher-quality $\mathrm{Pu}$ from the pits of dismantled nuclear weapons would be used to fabricate a MOX fuel for once-through burn-up followed by direct disposal of the used MOX fuel. The "scrap" or less pure $\mathrm{Pu}$ was to be immobilized in a titanate ceramic, the dominant phase being a Hf-bearing pyrochlore, (U,Pu,Hf,Gd) ${ }_{2} \mathrm{Ti}_{2} \mathrm{O}_{7}$. A considerable amount of research has been completed on phases suitable for immobilization of $\mathrm{Pu}$, including pyrochlore and related structure-types (Lutze \& Ewing 1988, Donald et al. 1997, Lumpkin et al. 2004). In April of 2002, the U.S. 
stopped almost all work on the $\mathrm{Pu}$-immobilization strategy in favor of accelerated conversion of Pu into MOX fuel. This decision still leaves the fate of the "scrap" plutonium, approximately 5-7 t that is not suitable for use in MOX fuel, unresolved. Although research on the immobilization of $\mathrm{Pu}$ in crystalline ceramics has mostly ended in the United States, work continues in a number of other countries, mainly Russia, Australia, United Kingdom and France.

Regardless of the strategy pursued, either for the use or disposal of plutonium, the development of new materials, either for storage (for tens to hundreds of years), or for disposal (for tens to hundreds of thousands of years) is still required in order to insure that there is no release of $\mathrm{Pu}$ to the environment during storage or after disposal. The materials used for immobilization generally have relatively complex compositions, so that they can incorporate actinides (as well as neutron absorbers, such as Gd and Hf, and highly radioactive fission products, such as $\mathrm{Cs}$ and $\mathrm{Sr}$ ), their synthesis must be accomplished remotely, the phases must be chemically durable, and their physical and chemical properties should not be degraded by irradiation from $\alpha$-decay events from the incorporated actinides.

In this paper, I present some of the recent developments in the properties of materials considered for the immobilization of actinides, particularly plutonium. There have been a number of extensive reviews and comparisons of nuclear waste forms (Lutze \& Ewing 1988, Ewing et al. 1995, Donald et al. 1997, Lumpkin et al. 2004). Some of the phases that have received the most attention for actinide immobilization include: zircon (Ewing 1999, 2001, Ewing et al. 2003), titanates (Lumpkin 2001, Lumpkin et al. 2004), phosphates (Ewing \& Wang 2002) and pyrochlore (Ewing et al. 2004a, Ewing 2005). Because of the very recent advances in our understanding of radiation damage effects in pyrochlore-group phases, I focus on this subject in this paper.

\section{Pyrochlore}

There are over 500 synthetic compositions of the pyrochlore structure-type (Chakoumakos 1984), including actinides (Chakoumakos \& Ewing 1985). A number of compositions containing thorium and uranium (Laverov et al. 2001, 2002, 2003), as well as transuranium elements (e.g., $\mathrm{Cm}$ and $\mathrm{Pu}$ ), have been synthesized (Weber et al. 1985a, b, Raison et al. 1999, Kulkarni et al. 2000). Thus it is not surprising that the pyrochlore structure-type has received extensive attention as a potential host-phase for actinides (Ewing et al. 2004a).

\section{The structure of pyrochlore-group phases}

Pyrochlore is isometric $(F d 3 m, Z=8, a$ in the range 0.9 to $1.2 \mathrm{~nm}$ ), and the structural formula is ideally
${ }^{\mathrm{VIII}} A_{2}{ }^{\mathrm{VI}} B_{2}{ }^{\mathrm{IV}} X_{6}{ }^{\mathrm{IV}} Y$ (Roman numerals indicate the coordination number), where the $A$ and $B$ sites contain metal cations; $X\left(=\mathrm{O}^{2-}\right)$ and $Y\left(=\mathrm{O}^{2-}, \mathrm{OH}^{-}, \mathrm{F}^{-}\right)$are anions (Chakoumakos 1984, Subramanian et al. 1983). The structure can be described in a variety of ways, most commonly by describing the shapes and topology of the coordination polyhedra (Fig. 4a). Pyrochlore is closely related to the fluorite structure $\left(A X_{2}\right)$, except that there are two cation sites and one-eighth of the anions are absent (Figs. 4c, d). The cations and oxygen vacancies are ordered. The loss of one-eighth of the anions reduces the coordination of the $B$-site cation from eight to six. The $X$ anion occupies the $48 f$ position, and the $Y$ anion, the $8 \mathrm{~b}$ position (if the origin of the unit cell is placed at the $B$ site). All of the atoms in an ideal pyrochlore are on special crystallographic positions, except the $48 f$ oxygen $\left(\mathrm{O}_{48 \mathrm{f}}\right)$. The structure can also be visualized as a network of corner-linked $B X_{6}$ octahedra (a $B_{2} X_{6}$ framework) with $A$-site cations filling the interstices (Fig. 4a). The $A$ - and $B$-site coordination polyhedra share edges, and the shapes of these polyhedra change as the positional parameter, $x$, of the $\mathrm{O}_{48 \mathrm{f}}$ shifts to accommodate cations of different sizes ( $x$ is simply a positional coordinate within the unit cell for $\left.\mathrm{O}_{48 f}\right)$. For $x=0.3750$, the $A$-site coordination polyhedron is a regular cube, and the $B$-site polyhedron is distorted to a trigonally flattened octahedron (the topology of the fluorite structure). In this case, materials have a defect fluorite structure, and the occupancy of each anion site is 0.875 . For $x=0.3125$, the $B$ site is a regular octahedron, and the $A$ site is a distorted trigonal scalenohedron; the phase has the ideal pyrochlore structure (Chakoumakos 1984, Subramanian et al. 1983). Thus, the $48 f$ oxygen positional parameter, $x$, defines the distortion of the polyhedron and structural deviation from the ideal structure of fluorite.

In ternary metal oxide systems, the pyrochlore structure-type, $A_{2} B_{2} \mathrm{O}_{7}$, is common because this isometric structure can accommodate a wide variety of combinations of $A$ - and $B$-site cations $\left(3^{+}\right.$and $4^{+}$or $2^{+}$and $5^{+}$), as well as oxygen vacancies (Subramanian et al. 1983). The $\left(3^{+}, 4^{+}\right)$pyrochlores are of greatest interest in nuclear waste management because of their ability to incorporate trivalent lanthanides and tri- and tetravalent actinides (Subramanian et al. 1983). Of the most typical $B$-site compositions (e.g., Ti, V, Cr, Sn and Mo), the titanates have received the most attention because of their chemical durability. An extensive literature exists on the properties of lanthanide titanates (Ewing et al. 2004a). Data for actinide pyrochlores are limited; however, Chakoumakos \& Ewing (1985) have used the pyrochlore unit-cell geometry to analyze the potential of the pyrochlore structure to incorporate actinides. Actinides $\left(3^{+}, 4^{+}\right.$, and $\left.5^{+}\right)$are predicted to form the pyrochlore structure by substitutions at both the $A$ and $B$ sites. Higher-valence states (e.g., $\mathrm{Np}^{6+}$ and $\mathrm{Pu}^{6+}$ ) can be incorporated into ideal or defect pyrochlores at the $B$ site. 
(a)

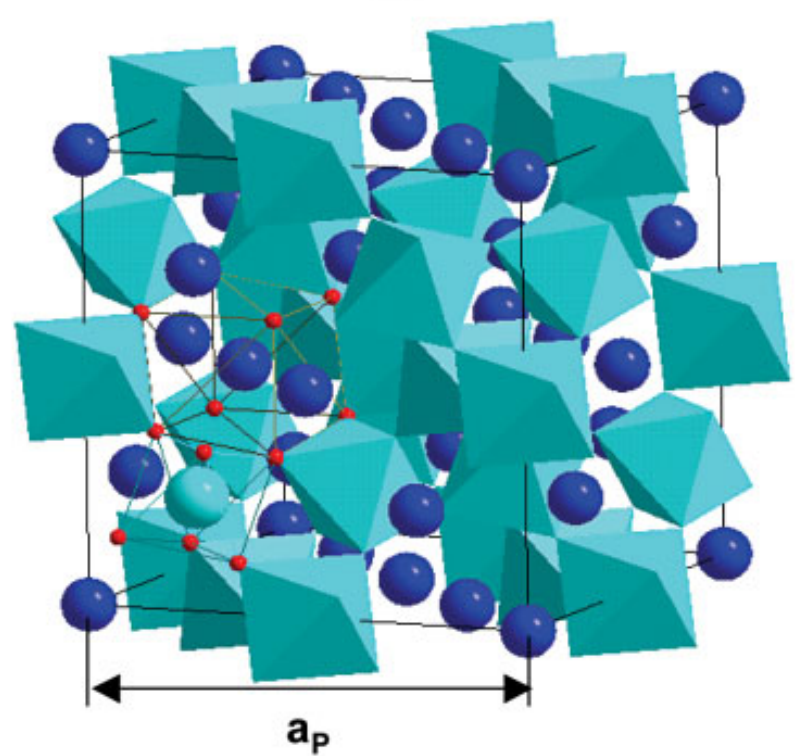

(c)

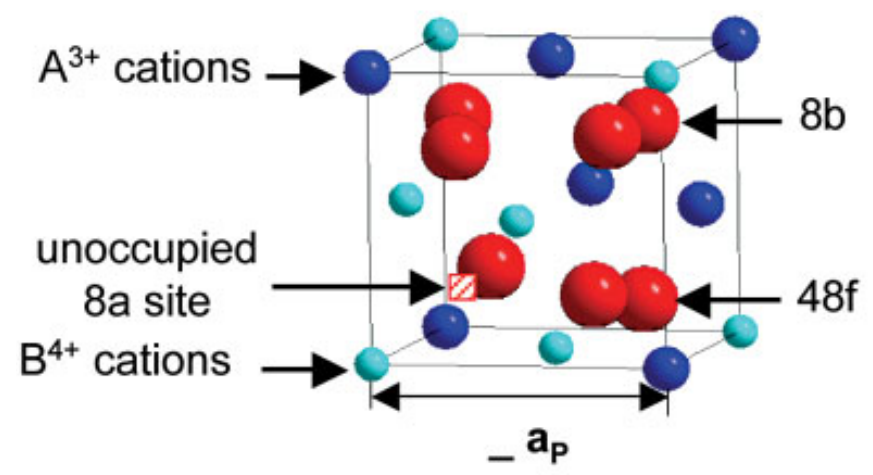

(b)
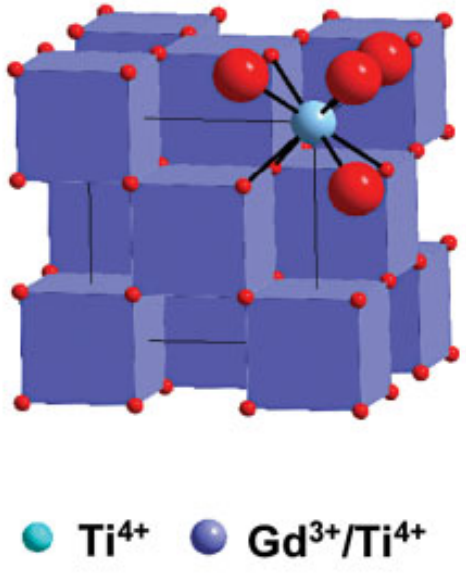

$\mathrm{Gd}^{3+} \mathrm{O}^{2-}$

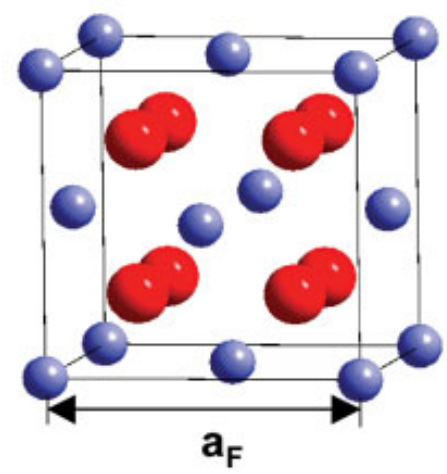

FIG. 4. Pyrochlore structure described on the basis of the polyhedron network (a) and the derivative of fluorite structure (c). Corresponding fluorite unit cell $(b, d)$ are included for comparison. Note, in this figure, that the origin of the unit cell is set at the position of the $B$-site cation. There are two types of oxygen atoms ( $8 b: Y$ anion, $48 f: X$ anion), and one-eighth of the oxygen atoms are missing, at the $8 a$ site. In the defect fluorite structure (d), all of the anion sites are partially filled owing to disorder of the anions over all of the anion sites; the occupancy at each site is $88 \%$.

\section{Radiation effects}

A principal concern for actinide waste forms is the effect of the $\alpha$-decay event on the crystalline structure of the waste form (Ewing et al. 1995, Weber et al. 1997, 1998). In an $\alpha$-decay event, the $\alpha$ particle dissipates most of its energy (4.5 to $5.8 \mathrm{MeV}$ for actinides) by ionization processes over a range of 15 to $22 \mu \mathrm{m}$, but undergoes enough elastic collisions along its path to produce several hundred isolated atomic displacements. The largest number of displacements occurs near the end of the $\alpha$-particle range. The more massive, but lower energy, $\alpha$-recoil $\left(86 \mathrm{keV}^{235} \mathrm{U}\right.$ recoil from decay of ${ }^{239} \mathrm{Pu}$ ) dissipates nearly all of its energy in elastic collisions over a very short range, 30 to $40 \mathrm{~nm}$, causing $\sim 1,000$ atomic displacements. The density of energy deposited into the cascade is high (up to $1 \mathrm{eV} /$ atom) and occurs over an extremely short time $\left(<10^{-12} \mathrm{~s}\right)$. Thus, 
a single $\alpha$-decay event generates approximately 1200 atomic displacements, significantly more than the 0.1 displacements generated per $\beta$-decay event. Because of the large number of atomic displacements during an $\alpha$-decay event, there is a profound effect on the structure and properties of crystalline solids that incorporate actinides. The cumulative effect of dose will be time- and temperature-dependent because of relaxation and recrystallization of damaged areas (Helean et al. 2004). Radiation effects from $\alpha$-decay events in many crystalline phases proposed for the immobilization of actinides result in amorphization, macroscopic swelling, and order-of-magnitude increases in dissolution rates (Ewing et al. 1995). In a detailed study on the effects of $\alpha$-decay on single-phase $(\mathrm{Gd}, \mathrm{Cm})_{2} \mathrm{Ti}_{2} \mathrm{O}_{7}$ pyrochlore, Weber et al. (1986) determined that amorphization occurred at a dose of about $3.1 \times 10^{18} \alpha$-decay events per gram and was accompanied by macroscopic swelling of about $5 \%$ and an increase, by a factor of 20 to 50 , in the rate of aqueous dissolution of the non-networkforming $\mathrm{Cm}$. The radiation-induced transformation to an amorphous state and the magnitude of the changes in swelling and dissolution rate are greatly dependent on the composition of the pyrochlore and the conditions of irradiation. Because self-radiation damage from $\alpha$ decay can significantly affect the atomic-scale structure and the physical and chemical properties of actinidebearing pyrochlore-based waste forms, any long-term assessments of performance must take into account the effects of $\alpha$-decay at relevant temperatures, dose rates, and times. In this regard, it is fortunate that systematic experimental studies using short-lived actinides and ion-beam irradiations, investigations of radiation effects in $\mathrm{U}$ - and Th-bearing minerals, and the development of new models of radiation damage processes over the past 20 years have led to significant improvements in understanding the processes of damage accumulation in pyrochlore and related defect-fluorite structures (Ewing et al. 2004a).

\section{Ion-beam simulation of $\alpha$-decay damage}

Ion-beam irradiations can be used to simulate $\alpha$-decay event damage under carefully controlled experimental conditions (e.g., ion mass and energy, temperature and fluence) (Ewing et al. 2000). Most experiments have been performed in situ generally using the IVEM-Tandem or HVEM-Tandem (now dismantled) facilities at Argonne National Laboratory. There, a $2 \mathrm{MeV}$ tandem ion accelerator is interfaced with high- and intermediate-voltage electron microscopes, 800 and $300 \mathrm{kV}$, respectively. During an ionbeam irradiation, one can simultaneously observe microstructural changes in the pre-thinned sample using in situ transmission electron microscopy (TEM). The critical amorphization fluence (ions $/ \mathrm{cm}^{2}$ ), $\mathrm{D}_{\mathrm{c}}$, is the fluence at which all of the diffraction maxima in the selected-area electron-diffraction pattern disappear, and the sample is considered to be amorphous. Typically, the fluence (ions $/ \mathrm{cm}^{2}$ ) is converted to units of displacements per atom (dpa) in order to facilitate the comparison of radiation effects on different materials subjected to different types of radiation (e.g., a high-energy ion versus an $\alpha$-decay recoil atom: Ewing et al. 2000). The conversion requires a knowledge of the minimum energy required to permanently displace an atom from its position in the structure (i.e., generally assumed to be $\sim 50 \mathrm{eV}$ for all atoms in pyrochlore structure) and the use of a code, SRIM (the Stopping and Range of Ions in Matter). The radiation-induced transformation from the crystalline-to-amorphous state is a balance between the production of damage and damage-recovery processes; thus, the critical dose for amorphization increases at elevated temperatures of irradiation owing to recovery processes. Complete amorphization will not occur if the amorphization rate is less than or equal to the damage-recovery rate. The temperature at which the rate of damage recovery equals the damage rate is defined as the critical temperature, $T_{c}$, for amorphization of a given material under a specific set of irradiation conditions. Different mechanisms have been proposed for ion-beam-irradiation-induced amorphization processes (Weber 2000), and the effects of ion species, energy, target mass and irradiation temperatures on $\mathrm{T}_{\mathrm{c}}$ have been review by Wang et al. (2001). Depending on the purpose of the comparison, $\mathrm{T}_{\mathrm{c}}$ or the amorphization dose at room temperature or $25 \mathrm{~K}$ may be used to characterize a material's stability under irradiation.

Systematic ion-beam irradiations have been completed using a variety of ion sources: $600 \mathrm{keV} \mathrm{Ar}^{+}$,

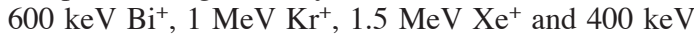
$\mathrm{Au}^{+}$for pyrochlore-structured compounds, $A_{2} B_{2} \mathrm{O}_{7}\left(A^{3+}\right.$ : $\mathrm{La} \rightarrow \mathrm{Lu}$ and $\mathrm{Y} ; B^{4+}=\mathrm{Ti}, \mathrm{Sn}, \mathrm{Hf}, \mathrm{Zr}$, etc.). Surprisingly, the different compositions of pyrochlore display a wide range of responses to ion-beam-induced amorphization. All of the titanate pyrochlores were readily amorphized by ion-beam irradiation at a relatively low damagelevel [see Ewing et al. (2000) for a discussion of the conversion of ion fluence (ions $/ \mathrm{cm}^{2}$ ) to displacements per atom (dpa)]. $\mathrm{Gd}_{2} \mathrm{Ti}_{2} \mathrm{O}_{7}$ can be amorphized by 600 $\mathrm{keV} \mathrm{Ar}^{+}$at room temperature at $\sim 0.2 \mathrm{dpa}$ (Wang et al. 1999a), a value that is consistent with the amorphization dose ( 0.16 dpa) for ${ }^{244} \mathrm{Cm}$-doped (3 wt. \%) $\mathrm{Gd}_{2} \mathrm{Ti}_{2} \mathrm{O}_{7}$ (Weber et al. 1986). Also, an ion-beam-induced pyrochlore-to-fluorite structural transition (a result of disordering of the cations on the $A$ and $B$ sites) was observed concurrently with the amorphization process for all of the titanate pyrochlores (Wang et al. 1999a, 2000). The temperature dependences of the critical dose for amorphization for titanate pyrochlore single crystals under $1 \mathrm{MeV} \mathrm{Kr}{ }^{+}$ion irradiation are shown in Figure 5. A significant difference in the radiation response of the titanate pyrochlores with different lanthanide elements occupying the $A$ site was observed. Generally, with increasing ionic radius of the $A$-site cation, from $\mathrm{Lu}^{3+}$ $(0.098 \mathrm{~nm})$ to $\mathrm{Gd}^{3+}(0.106 \mathrm{~nm})$, the critical temperature 
of amorphization increases from $480 \mathrm{~K}$ (for $\mathrm{Lu}_{2} \mathrm{Ti}_{2} \mathrm{O}_{7}$ ) to $1120 \mathrm{~K}$ (for $\mathrm{Gd}_{2} \mathrm{Ti}_{2} \mathrm{O}_{7}$ ) (Fig. 5). However, with increase in the ionic radius of the $A$-site cation from $\mathrm{Gd}^{3+}(0.106 \mathrm{~nm})$ to $\mathrm{Sm}^{3+}(0.109 \mathrm{~nm})$, the critical temperature decreased slightly from $1120 \mathrm{~K}$ to $1045 \mathrm{~K}$. The fact that $\mathrm{Gd}_{2} \mathrm{Ti}_{2} \mathrm{O}_{7}$ has the highest $\mathrm{T}_{\mathrm{c}}$ indicates that this composition is the most susceptible to ion-irradiationinduced amorphization, as compared with the other rare-earth titanate pyrochlores. This finding is unfortunate, as the $\mathrm{Gd}_{2} \mathrm{Ti}_{2} \mathrm{O}_{7}$ composition was one of the main candidates for immobilization of $\mathrm{Pu}$.

One of the recent and exciting outcomes from systematic studies of irradiation effects in different pyrochlore-group compositions was the discovery of the radiation "resistance" of $\mathrm{Gd}_{2} \mathrm{Zr}_{2} \mathrm{O}_{7}$ and $\mathrm{Er}_{2} \mathrm{Zr}_{2} \mathrm{O}_{7}$ (Wang et al. 1999b, Sickafus et al. 2000, Lian et al. 2002, Ewing et al. 2004a). These compositions can readily accommodate $\mathrm{Pu}$ on the $\mathrm{Gd}$ (or $\mathrm{Er}$ ) and $\mathrm{Zr}$ sites (Williford \& Weber 2001). In the case of the $\mathrm{Gd}_{2}\left(\mathrm{Zr}_{\mathrm{x}} \mathrm{Ti}_{1-\mathrm{x}}\right)_{2} \mathrm{O}_{7}$ binary, there is a systematic increase in the radiation "resistance" (i.e., a decrease in $\mathrm{T}_{\mathrm{c}}$ and increase in the amorphization dose at $0 \mathrm{~K}, \mathrm{D}_{\mathrm{o}}$, which is obtained by extrapolation) with increasing $\mathrm{Zr}$-content under 1.0 MeV Kr ${ }^{+}$irradiation (Wang et al. 1999b). Complete amorphization cannot be achieved for Zr-rich pyrochlore compositions with $x \geq 0.75$ (Fig. 6). The end-member zirconate, $\mathrm{Gd}_{2} \mathrm{Zr}_{2} \mathrm{O}_{7}$, remained crystalline at a dose of $\sim 36 \mathrm{dpa}$ under $1.5 \mathrm{MeV} \mathrm{Xe}{ }^{+}$irradiation at $\mathrm{T}=25 \mathrm{~K}$ and at a dose of $\sim 100 \mathrm{dpa}$ for $200 \mathrm{keV} \mathrm{Ti}{ }^{+}$ implantation at room temperature (Lian et al. 2002). The high "resistance" of zirconate pyrochlore to ion-beaminduced amorphization was also confirmed for $\mathrm{Er}_{2} \mathrm{Zr}_{2} \mathrm{O}_{7}$ (Sickafus et al. 2000). In contrast to $\mathrm{Er}_{2} \mathrm{Ti}_{2} \mathrm{O}_{7}$ with an ordered pyrochlore structure, $\mathrm{Er}_{2} \mathrm{Zr}_{2} \mathrm{O}_{7}$, has a defect fluorite structure that readily accommodates radiationinduced structural disorder and remains crystalline at a dose of $\sim 140$ dpa at room temperature $\left(350 \mathrm{keV} \mathrm{Xe}{ }^{+}\right.$ irradiations). These results are consistent with recent molecular dynamics results that indicate that amorphization occurs directly within displacement cascades in $\mathrm{Gd}_{2} \mathrm{Ti}_{2} \mathrm{O}_{7}$, whereas in $\mathrm{Gd}_{2} \mathrm{Zr}_{2} \mathrm{O}_{7}$, displacement cascades tend to produce only point defects (Purton \& Allan 2002). In addition to $\mathrm{Gd}_{2} \mathrm{Zr}_{2} \mathrm{O}_{7}$ and $\mathrm{Er}_{2} \mathrm{Zr}_{2} \mathrm{O}_{7}, \mathrm{Sm}_{2} \mathrm{Zr}_{2} \mathrm{O}_{7}$ and $\mathrm{Nd}_{2} \mathrm{Zr}_{2} \mathrm{O}_{7}$ also transform from a pyrochlore structure to a defect-fluorite structure under irradiation with 1.5 $\mathrm{MeV} \mathrm{Xe} \mathrm{Xe}^{+}$ions (Lian et al. 2002), similar to the transition that occurs for the titanate pyrochlore compositions (Lian et al. 2003, 2004a); however, the resulting defect-fluorite structure, containing $\mathrm{Zr}$, remains resistant to amorphization at doses up to $7 \mathrm{dpa}$ at $25 \mathrm{~K}$ (Lian et al. 2002). Of all of the rare-earth- and $\mathrm{Zr}$-bearing pyrochlores, only $\mathrm{La}_{2} \mathrm{Zr}_{2} \mathrm{O}_{7}$ can be amorphized, but the critical temperature is low, $310 \mathrm{~K}$ (Lian et al. 2002, 2004a). Recent molecular dynamics simulations of 6 $\mathrm{keV} \mathrm{U}$ displacement cascades in $\mathrm{La}_{2} \mathrm{Zr}_{2} \mathrm{O}_{7}$ at $350 \mathrm{~K}$ indicate formation of a small number of point defects and a transition toward the defect-fluorite structure, consistent with the experimental observations (Charties et al. 2002).

The radiation response of two Gd-dominant pyrochlore compositions, $\mathrm{Gd}_{2} \mathrm{Sn}_{2} \mathrm{O}_{7}$ and $\mathrm{Gd}_{2} \mathrm{Hf}_{2} \mathrm{O}_{7}$, has been studied under a $1 \mathrm{MeV} \mathrm{Kr}^{+}$irradiation (Fig. 7), and the radiation damage and microstructural evolution were examined by in situ TEM and ex situ high-resolution TEM (Lian et al. 2004b). $\mathrm{Gd}_{2} \mathrm{Sn}_{2} \mathrm{O}_{7}$ is sensitive to ion beam-induced amorphization with a critical amorphization dose of $\sim 3.4 \mathrm{dpa}$ at room temperature and has a $\mathrm{T}_{\mathrm{c}}$ of $\sim 350 \mathrm{~K}$ (Lian et al. 2004b). In contrast, $\mathrm{Gd}_{2} \mathrm{Hf}_{2} \mathrm{O}_{7}$ does not become amorphous at a dose of $\sim 4.54$ dpa at room temperature, but instead is transformed to a disordered fluorite structure, similar to that observed for zirconate pyrochlores (Lian et al. 2002, 2004b). Combined with the irradiation results of titanate and zirconate pyrochlores, these results highlight the significant effects of the type of cation, at both the $A$ and $B$ site, on the radiation response of the pyrochlore structure (Fig. 7).

\section{The effect of the cations}

The radiation response of pyrochlore is highly dependent on composition, and this has been interpreted as being related to the ratio of the ionic radii of the $A$ - and $B$ - site cations, $\mathrm{r}_{\mathrm{A}} / \mathrm{r}_{\mathrm{B}}$, (Lian et al. 2002, 2003, Ewing et al. 2004b). Energy-minimization calculations (Sickafus et al. 2000) have suggested that the cation antisite defect is the most stable defect in the pyrochlore structure. As the radius of the $A$-site cation approaches that of the $B$-site cation, the material is more likely to adopt the fluorite structure-type. Thus, pyrochlore compositions with a lower cation radius-ratio energetically favor the disordered defect-fluorite structure, rather than the amorphous state (Helean et al. 2004). Figure 8 shows the critical temperature as a function of cation radius-ratio for all pyrochlore compositions irradiated by $1.0 \mathrm{MeV} \mathrm{Kr}^{+}$ions. Generally, with the decreasing ionic radius ratio, materials have a lower critical temperature of amorphization, suggesting a higher "resistance" to radiation and ion-beam-induced amorphization (Fig. 8). The change in the radiation "resistance" to ion-beam-induced amorphization is consistent in terms of the temperature of critical amorphization, $\mathrm{T}_{\mathrm{c}}$, and the amorphization dose at ambient conditions. For example, the ionic size of $\mathrm{Sn}^{4+}(0.069$ $\mathrm{nm})$ is midway between the ionic radii of $\mathrm{Ti}^{4+}(0.0605$ $\mathrm{nm})$ and $\mathrm{Zr}^{4+}(0.072 \mathrm{~nm})$, and the ionic radius of $\mathrm{Gd}^{3+}$ is $0.1053 \mathrm{~nm}$. Thus it is expected that $\mathrm{Gd}_{2} \mathrm{Sn}_{2} \mathrm{O}_{7}$, with $\mathrm{r}_{A} / \mathrm{r}_{B}$ $=1.526$, would more likely disorder to the defect fluorite structure than $\mathrm{Gd}_{2} \mathrm{Ti}_{2} \mathrm{O}_{7}\left(\mathrm{r}_{A} / \mathrm{r}_{B}=1.74\right)$. The critical data for amorphization dose at room temperature, $\mathrm{D}_{\mathrm{c}}$, and critical temperature, $\mathrm{T}_{\mathrm{c}}$, for $\mathrm{Gd}_{2} \mathrm{Sn}_{2} \mathrm{O}_{7}$ are $\sim 3.4 \mathrm{dpa}$ and $350 \mathrm{~K}$ (Lian et al. 2004b), respectively, suggesting a much higher "resistance" to amorphization as compared with that of $\mathrm{Gd}_{2} \mathrm{Ti}_{2} \mathrm{O}_{7}(\sim 0.2 \mathrm{dpa}$ and $1120 \mathrm{~K})$ (Lian et 
al. 2003). In the binary system of $\mathrm{Gd}_{2}\left(\mathrm{Ti}_{1-x} \mathrm{Zr}_{x}\right)_{2} \mathrm{O}_{7}$, the critical dose for amorphization increases dramatically with the decreasing cation radius-ratio owing to the substitution of $\mathrm{Zr}^{4+}$ for the smaller $\mathrm{Ti}^{4+}$, and complete amorphization cannot be induced by ion-beam irradiation if $x \geq 0.75$ [e.g., $\mathrm{Gd}_{2}\left(\mathrm{Ti}_{0.25} \mathrm{Zr}_{0.75}\right)_{2} \mathrm{O}_{7}$ : Wang et al. 1999b]. The radius ratio for $\mathrm{Gd}_{2}\left(\mathrm{Ti}_{0.25} \mathrm{Zr}_{0.75}\right)_{2} \mathrm{O}_{7}$ is 1.523. Furthermore, because of the similarity of the

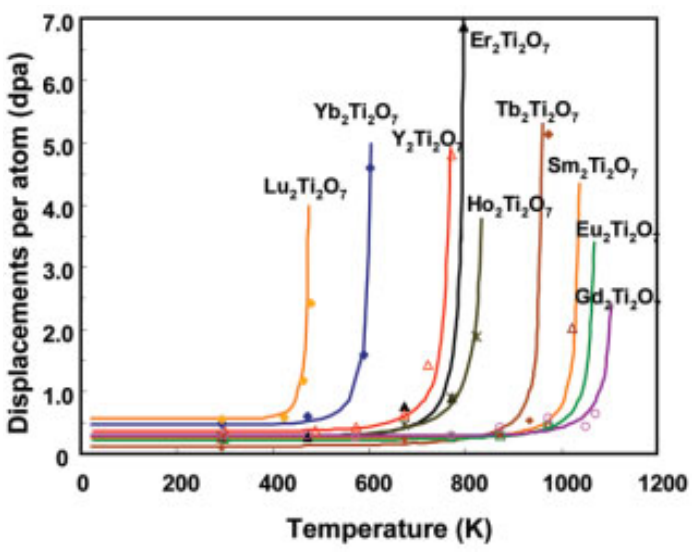

FIG. 5. Temperature dependence of the critical amorphization dose of $\mathrm{REE}_{2} \mathrm{Ti}_{2} \mathrm{O}_{7}$ irradiated by $1 \mathrm{MeV} \mathrm{Kr}$ irradiation (Lian et al. 2003). Note that each curve bends upward at elevated temperatures. For each material there is a unique temperature, $T_{c}$, above which the material cannot be amorphized. That temperature shifts dramatically depending on the composition of the $A$-site cation in the pyrochloregroup phase.

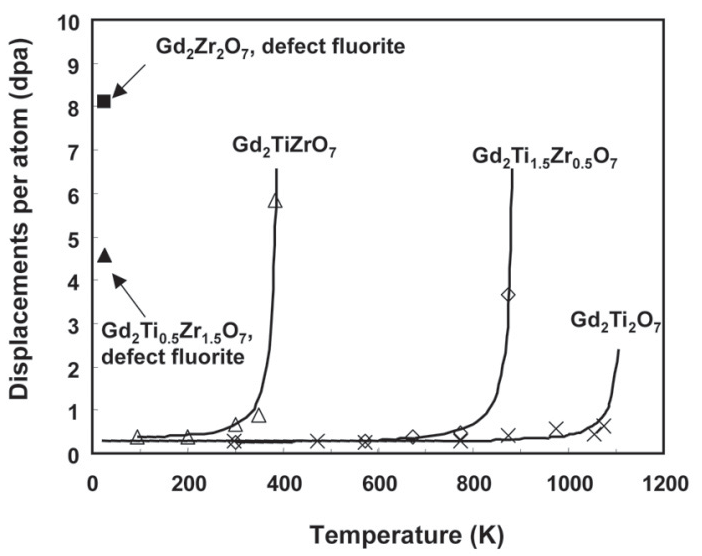

FIG. 6. Temperature dependence of the critical amorphization dose of $\mathrm{Gd}_{2}\left(\mathrm{Ti}_{1-x} \mathrm{Zr}_{x}\right)_{2} \mathrm{O}_{7}$ irradiated by $1 \mathrm{MeV} \mathrm{Kr}^{+}$(Wang et al. 1999b). For $\mathrm{Gd}_{2} \mathrm{Zr}_{2} \mathrm{O}_{7}$, amorphization does not occur; instead, the structure disorders to a defect fluorite structure-type, which is "resistant" to radiation. ionic radii of $\mathrm{Hf}^{4+}(0.71 \AA)$ and $\mathrm{Zr}^{4+}(0.72 \AA)$, it is expected that $\mathrm{Gd}_{2} \mathrm{Hf}_{2} \mathrm{O}_{7}\left(\mathrm{r}_{A} / \mathrm{r}_{B}=1.48\right)$ would exhibit an excellent "resistance" to amorphization, comparable to that of $\mathrm{Gd}_{2} \mathrm{Zr}_{2} \mathrm{O}_{7}\left(\mathrm{r}_{A} / \mathrm{r}_{B}=1.46\right)$ (Lian et al. 2004b). Therefore, ion-irradiation-induced defect fluorite in $\mathrm{Gd}_{2} \mathrm{Hf}_{2} \mathrm{O}_{7}$ is stable with respect to the amorphous state, similar to that observed for ion-irradiated $\mathrm{Gd}_{2} \mathrm{Zr}_{2} \mathrm{O}_{7}$. Also, the thermally driven, order-disorder structural transition occurs at about $1800 \mathrm{~K}$ for $\mathrm{Gd}_{2} \mathrm{Hf}_{2} \mathrm{O}_{7}$, consistent with that of $\mathrm{Gd}_{2} \mathrm{Zr}_{2} \mathrm{O}_{7}(1823 \mathrm{~K})$ (Wuensch \& Eberman 2000). These results are consistent with the tendency of pyrochlore structure-types toward an order-disorder transition, induced either by ion-beam irradiation or high-temperature annealing.

\section{Bond-type effects}

Although the ionic size of the cations plays an obvious and important role in determining the radiation response of various pyrochlore-group phases, recent work has shown a significant influence of the electronic configurations of the $A$ - and $B$-site cations (Lian et al. 2003). The effect of the electronic structure of a cation, i.e., the type of bonding, is closely related to the distortion of polyhedra and structural deviation from the ideal fluorite structure, which may affect the dynamic defectrecovery process. $\mathrm{Gd}_{2} \mathrm{Ti}_{2} \mathrm{O}_{7}$ has the highest critical temperature of amorphization, $\mathrm{T}_{\mathrm{c}}$, among titanate pyrochlore compositions, suggesting that this composition is more sensitive to ion-irradiation-induced amorphization as compared with other rare-earth titanate pyrochlores (Lian et al. 2003). This result is consistent with the fact that this composition has the greatest structural deviation from the ideal fluorite structure, as evidenced by the fact that it has the smallest $x$ parameter of the $48 f$ oxygen, as a result of the strong ionic character of $\mathrm{Gd}^{3+}$ owing to the specific electronic configuration of the $4 f$ subshell of $\mathrm{Gd}^{3+}$ (half-filled). The positional

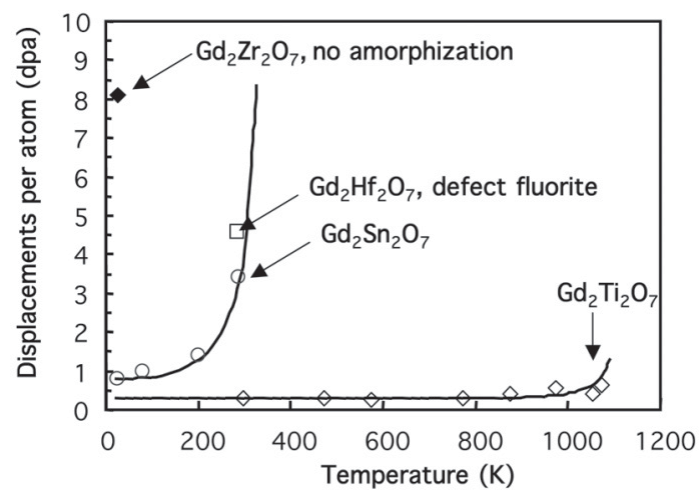

FIG. 7. Effect of $B$-site cations on the radiation response of Gd-dominant pyrochlore $\mathrm{Gd}_{2} B_{2} \mathrm{O}_{7}\left(B^{4+}=\mathrm{Ti}, \mathrm{Sn}, \mathrm{Hf}\right.$, and $\mathrm{Zr}$ ) under $1 \mathrm{MeV} \mathrm{Kr}{ }^{+}$irradiation (Lian et al. 2004b). 
parameter of the $48 f$ oxygen defines the polyhedron distortions and the deviation from the ideal fluorite structure, and it is closely affected by the relative ionic size of cations at the $A$ and $B$ sites, their electronic configuration and structural disorder. With an increasing $x$ value $\left(B^{4+}\right.$ as the origin of the unit cell, see Fig. 4c) and an increasing degree of structural disorder, the structure has greater distortion of the $B$-site coordination polyhedron and is closer to the ideal fluorite structure (Subramanian et al. 1983), and thus is more sensitive to ion-beam-induced amorphization. The effect of electronic configuration of the cation is further evidenced by the comparison between the radiation responses of $\mathrm{Gd}_{2} \mathrm{Sn}_{2} \mathrm{O}_{7}$ and $\mathrm{Gd}_{2}\left(\mathrm{Zr}_{0.75} \mathrm{Ti}_{0.25}\right)_{2} \mathrm{O}_{7}$. Although the cation radius-ratio of $\mathrm{Gd}_{2} \mathrm{Sn}_{2} \mathrm{O}_{7}(\sim 1.526)$ is similar to that of $\mathrm{Gd}_{2}\left(\mathrm{Zr}_{0.75} \mathrm{Ti}_{0.25}\right)_{2} \mathrm{O}_{7}(\sim 1.523)$, there is a dramatic difference in the radiation "resistance" (Fig. 8). No amorphization occurs in $\mathrm{Gd}_{2}\left(\mathrm{Zr}_{0.75} \mathrm{Ti}_{0.25}\right)_{2} \mathrm{O}_{7}$ with an ion irradiation at $25 \mathrm{~K}$, whereas $\mathrm{Gd}_{2} \mathrm{Sn}_{2} \mathrm{O}_{7}$ can be amorphized at room temperature at a dose of $\sim 3.4$ dpa. The covalent character of the $<\mathrm{Sn}-\mathrm{O}>$ bond and the associated decrease in the $<\mathrm{Sn}-\mathrm{O}>$ bond distance imply a lesser degree of distortion of the $\mathrm{SnO}_{6}$ coordination octahedron, resulting in a structure more compatible with the ordered pyrochlore superstructure (Kennedy et al. 1997). This leads to a greater susceptibility of $\mathrm{Gd}_{2} \mathrm{Sn}_{2} \mathrm{O}_{7}$ to irradiation-induced amorphization, as compared with $\mathrm{Gd}_{2}\left(\mathrm{Zr}_{0.75} \mathrm{Ti}_{0.25}\right)_{2} \mathrm{O}_{7}$. Using first-principle calculations, and using density functional theory, Panero et al. (2004) have reported a significant covalency for the $<\mathrm{Sn}-\mathrm{O}>$ bond and mainly ionic character for the $\langle\mathrm{Ti}-\mathrm{O}\rangle$ and $\langle\mathrm{Zr}-\mathrm{O}\rangle$ bonds. The greater degree

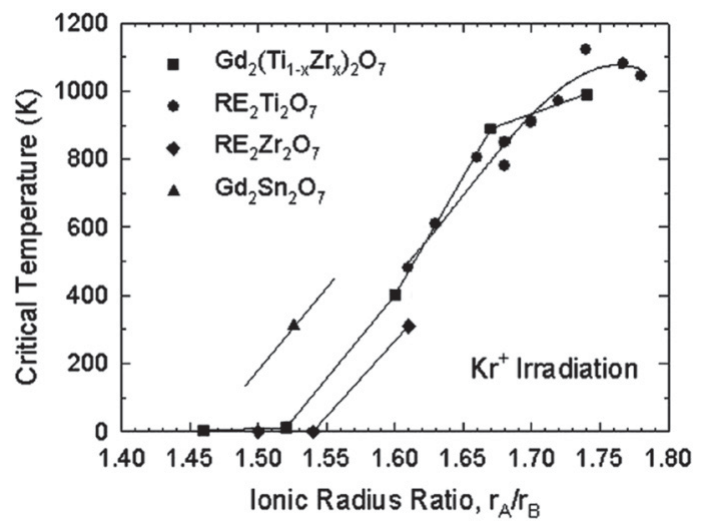

FIG. 8. Critical temperature as a function of cation radiusratio, $\mathrm{r}_{\mathrm{A}} / \mathrm{r}_{\mathrm{B}}$, for all pyrochlore compositions irradiated by 1.0 $\mathrm{MeV} \mathrm{Kr}^{+}$(Ewing et al. 2004a). RE: rare-earth element. $\mathrm{La}_{2} \mathrm{Zr}_{2} \mathrm{O}_{7}$ was irradiated by $1.5 \mathrm{MeV} \mathrm{Xe}^{+}$(Lian et al. 2002). Note that as the critical temperature decreases, the radiation "resistance" of the composition increases, i.e., annealing dominates the damage-accumulation process. Certain compositions, like $\mathrm{Gd}_{2} \mathrm{Zr}_{2} \mathrm{O}_{7}$, disorder to the defect fluorite structure but never become amorphous. of covalent bonding in $\left\langle\mathrm{Sn}^{4+}-\mathrm{O}\right\rangle$ as compared with $<\mathrm{Ti}^{4+}-\mathrm{O}>$ or $<\mathrm{Zr}^{4+}-\mathrm{O}>$ results in defect-formation energies otherwise unexpected solely due to the radius ratios of the cation species. For example, $\mathrm{Y}_{2} \mathrm{Sn}_{2} \mathrm{O}_{7}$ shows a 2-4 eV greater defect-formation energy than otherwise predicted by the use of the average $B$-site cation size. This underscores the importance of the electronic configuration of cations on the crystal chemistry and the radiation "tolerance" of the pyrochlore structure.

\section{Future RESEARCH ON ACTINIDE WASTE-Forms}

I have discussed the radiation response of different pyrochlore compositions in order to illustrate the present level of understanding of radiation effects in phases that may be used for the immobilization of $\mathrm{Pu}$ and the minor actinides. This fundamental understanding has emerged from systematic and complementary studies on $\alpha$-decay damage (in actinide-doped and natural samples) and ion-beam irradiations of different pyrochlore compositions. It is now possible to predict the dose and, thus, the time dependence of amorphization in several actinide-host phases, such as pyrochlore, under repository conditions. As an example, whereas $\mathrm{Gd}_{2} \mathrm{Ti}_{2} \mathrm{O}_{7}$ (with a $10 \mathrm{wt}$ \% loading of ${ }^{239} \mathrm{Pu}$ ) will require less than a thousand years to amorphize, $\mathrm{Gd}_{2} \mathrm{Zr}_{2} \mathrm{O}_{7}$ will not amorphize. A similar level of understanding must be obtained for the mechanisms of corrosion of the different actinide waste-forms, but there is already substantial progress in this area (Lumpkin et al. 2004). I believe that in the future, with a solid research base, it will be possible to design nuclear waste-forms for particular radionuclides and for the specific geochemical and hydrological environments of a particular repository location. With the present work as a starting point, investigators should use this understanding to improve the safety and efficiency of other materials used in the nuclear fuel cycle. There must be a similar effort to design materials for carbon sequestration. In this case, the challenge is different in both the scale of the volume of material that requires sequestration and the time over which the material must remain stable. From the perspective of comparison of the size of the "footprint" between the sequestration of plutonium versus carbon, the environmental impact of $\mathrm{Pu}$-sequestration may be considerably less.

\section{ACKNOWLEDGEMENTS}

In this paper, I have drawn heavily on two previous reviews in the Journal of Applied Physics (Ewing et al. 2004a) and Earth and Planetary Science Letters (Ewing 2005) and a chapter in Energy, Waste and the Environment: a Geochemical Perspective (Ewing 2004). All of this work has benefitted from extended collaborations with Lu Min Wang, Shi Xin Wang, Jie Lian at the University of Michigan, Bill Weber at Pacific Northwest National Laboratory, Alex Navrotsky and Kate Helean at the University of California, Davis, Greg Lumpkin at 
Cambridge University, and Al Meldrum at the University of Alberta. This paper has benefitted considerably from the reviews by Kate Helean, Alex Navrotsky and Frannie Skomurski. I am especially grateful for the careful editing by Bob Martin. This work would not have been possible without the sustained support the Office of Basic Energy Sciences of the U.S. Department of Energy (DE-FG02-97ER45656). I am also grateful for the support of the John Simon Guggenheim Memorial Foundation for a fellowship that allowed me to stray far from my normal research path.

\section{REFERENCES}

Albright, D., Berkhout, F. \& Walker, W. (1997): Plutonium and Highly Enriched Uranium 1996 World Inventories, Capabilities and Policies. Oxford University Press, New York, N.Y.

\& KRAMER, K. (2004): Fissile materials: stockpiles still growing. Bull. Atomic Scientists 60, 14-16.

Ansolabehere, S., Deutch, J., Driscoll, M., Gray, P.E., Holdren, J.P., Joskow, P.L., Lester, R.K., Moniz, J. \& Todreas, N.E. (2003): The Future of Nuclear Power. Massachusetts Institute of Technology, Cambridge, Massachusetts.

Boczar, P.G., Gagnon, M.J.N., Chan, P.S.W., Ellis, R.J., Verrall, R.A. \& Dastur, A.R. (1997): Advanced CANDU systems for plutonium destruction. Can. Nuclear Soc. Bull. 18, 2-10.

BudNITZ, R.J. \& HoldRen, J.P. (1976): Social and environmental costs of energy systems. Аnпи. Rev. Energy 1, 553-580.

Bunn, M., Fetter, S., Holdren, J.P. \& van Der ZwaAn, B. (2003): The economics of reprocessing vs. direct disposal of spent nuclear fuel. In Project on Managing the Atom. Final Report, December, 2003, DE-FG26-99FT4028, 127 pages. Also available at: bcsia.ksg.harvard.edu/BCSIA content/documents/econ_reprocessing_m_bunn.pdf

\& HoldREN, J.P. (1997): Managing military uranium and plutonium in the United States and the former Soviet Union: current security challenges. In Annual Review of Energy and the Environment 22 (R.H. Socolow, D. Anderson \& J. Harte, eds.). Annual Reviews Inc., Palo Alto, California (403-486).

CARTER, L.J. (1987): Nuclear Imperatives and Public Trust. Resources for the Future, Inc., Washington, D.C. (473 p.).

\& PigfoRd, T.H. (1999): The world's growing inventory of civil spent fuel. Arms Control Today 8, 8-14.

Chakoumakos, B.C. (1984): Systematics of the pyrochlore structure type, ideal $\mathrm{A}_{2} \mathrm{~B}_{2} \mathrm{X}_{6} \mathrm{Y}$. J. Solid State Chem. 53, $120-129$

\& EwING, R.C. (1985): Crystal chemical constraints on the formation of actinide pyrochlores. In Scientific
Basis for Nuclear Waste Management VIII (C.M. Jantzen, J.A. Stone \& R.C. Ewing, eds.). Mater. Res. Soc., Symp. Proc. 44, 641-646.

Charties, A., Meis, C., Weber, W.J. \& Corrales, L.R. (2002): Theoretical study of disorder in Ti-substituted $\mathrm{La}_{2} \mathrm{Zr}_{2} \mathrm{O}_{7}$. Phys. Rev. B 65, 134116.

DEPARTMENT OF ENERgy (2002): A technology roadmap for Generation IV nuclear energy systems. U.S. Nuclear Energy Research Advisory Committee, GIF-002-00 (91 p.).

Donald, I.W., Metcalfe, B.L. \& TaYlor, R.N.J. (1997): The immobilization of high level radioactive wastes using ceramics and glasses. J. Mater. Sci. 32, 5851-5887.

EwING, R.C. (1999): Nuclear waste forms for actinides. Proc. Nat. Acad. Sci. 96, 3432-3439.

(2001): The design and evaluation of nuclearwaste forms: clues from mineralogy. Can. Mineral. 39, 697-715.

(2004): Environmental impact of the nuclear fuel cycle. In Energy, Waste, and the Environment: a Geochemical Perspective (R. Gieré \& P. Stille, eds.). Geol. Soc., Spec. Publ. 236, 7-23.

(2005): Plutonium and "minor" actinides: safe sequestration. Earth Planet. Sci. Lett. 229, 165-181.

LiAN, J. \& WANG, L.M. (2004b): Ion beam-induced amorphization of the pyrochlore structure-type: a review. In Radiation Effects and Ion Beam Modification of Materials (L.M. Wang, R. Fromknecht, L.L. Snead, D.F. Downey \& H. Takahashi, eds.). Mater. Res. Soc., Symp. Proc. 792, 37-48.

Meldrum, A., Wang, L.M. \& WANG, S.X. (2000): Radiation-induced amorphization. In Transformation Processes in Minerals (S.A.T. Redfern \& M.A. Carpenter, eds.). Rev. Mineral. Geochem. 39, 319-361.

Weber, W.J. \& CORRALES, R.E. (2003): Radiation effects in zircon. In Zircon (J.M. Hanchar \& P.W.O. Hoskin, eds.). Rev. Mineral. Geochem. 53, 387-425.

\& WANG, L.M. (2002): Phosphates as nuclear waste forms. In Phosphates - Geochemical, Geobiological and Materials Importance (M.J. Kohn, J. Rakovan \& J.M. Hughes, eds.). Rev. Mineral. Geochem. 48, 673-699.

Weber, W.J.\& Clinard, F.W., JR. (1995): Radiation effects in nuclear waste forms for high-level radioactive waste. Progress in Nuclear Energy 29, 63-127.

\& Lian, J. (2004a) Pyrochlore $\left(\mathrm{A}_{2} \mathrm{~B}_{2} \mathrm{O}_{7}\right)$ : a nuclear waste form for the immobilization of plutonium and "minor" actinides. J. Appl. Phys. 95, 5949-5971.

Falkowski, P., Scholes, R.J., Boyle, E., CAnadell, J., CANfield, D., Elser, J., Gruber, N., Hibbard, K., HögberG, 
P., Linder, S., Mackenzie, F.T., Moore, B., III, PederSen, T., Rosenthal, Y., Seitzinger, S., Smetacek, V. \& STEFFEN, W. (2000): The global carbon cycle: a test of our knowledge of Earth as a system. Science 290, 291-296.

FetTeR, S. (2000): Energy 2050. Bull. Atomic Scientists 56, 28-38.

Gong, W.L., LutZe, W. \& EwIng, R.C. (2000): Zirconia ceramics for excess weapons plutonium waste. J. Nuclear Mater. 277, 239-249.

Helean, K.B., Ushakov, S.V., Brown, C.E., NAvrotsky, A., Lian, J., Ewing, R.C., FARMer, J.M. \& Boatner, L.A. (2004): Formation enthalpies of rare earth titanate pyrochlores. J. Solid State Chem. 177, 1858-1866.

Houghton, J.T. (2000): Global Warming, The Complete Briefing. Cambridge University Press, Cambridge, U.K.

Ding, Y., Griggs, D.J. Noguer, M., van der Linden, P.J., Dai, Xiaosu, Maskell, K. \& Johnson, C.A., eds. (2001): Climate Change 2001: The Scientific Basis. Cambridge University Press, Cambridge, U.K.

Kennedy, B.J., HunTer, B.A. \& Howard, C.J. (1997): Structural and bonding trends in tin pyrochlore oxides. J. Solid State Chem. 130, 58-65.

Kulkarni, N.K., Sampath, S. \& Venugopal, V. (2000): Preparation and characterisation of Pu-pyrochlore: $\left(\mathrm{La}_{1-x}\right.$ $\left.\mathrm{Pu}_{x}\right)_{2} \mathrm{Zr}_{2} \mathrm{O}_{7}(x=0-1)$. J. Nucl. Materials 281, 248-250.

LaVerov, N.P., Velichion, V.I., OMel'yanenko, B.I. \& YUDINTSEV, S.V. (2003): Geochemistry of actinides during the long-term storage and disposal of spent nuclear fuel. Geology of Ore Deposits 45, 1-18.

YUdintsev, S.V., Stefanovsky, S.V. \& JANG, Y.N. (2001): New actinide matrix with pyrochlore structure. Dokl. Earth Sci. 381, 1053-1055.

\& EwING, R.C. (2002): Synthesis and examination of new actinide pyrochlores. In Scientific Basis for Nuclear Waste Management XXV (B.P. McGrail \& G.A. Cragnolino, eds.). Mater. Res. Soc., Symp. Proc. 713, 337-343.

Lian, Jie, Chen, Jian, Wang, L.M., Ewing, R.C., Farmer, J.M., BOATNER, L.A. \& HELEAN, K.B. (2003): Radiationinduced amorphization of rare-earth titanate pyrochlores. Phys. Rev. B68, 134107-1 - 134107-9.

Ewing, R.C., Wang, L.M. \& Helean, K.B. (2004b): Ion beam irradiation of $\mathrm{Gd}_{2} \mathrm{Sn}_{2} \mathrm{O}_{7}$ and $\mathrm{Gd}_{2} \mathrm{Hf}_{2} \mathrm{O}_{7}$ : bonding type effect. J. Mater. Res. 19, 1575-1580.

Wang, L.M., Haire, R.G., Helean, K.B. \& Ewing, R.C. (2004a): Ion beam irradiation effects in $\mathrm{La}_{2} \mathrm{Zr}_{2} \mathrm{O}_{7}-$ $\mathrm{Ce}_{2} \mathrm{Zr}_{2} \mathrm{O}_{7}$ pyrochlore. Nucl. Instrum. Methods Phys. Res. B218, 236-243.

Zu, X.T., Kutty, K.V.G., Chen, J., Wang, L.M. \& R.C. EwING (2002): Ion-irradiation-induced amorphi- zation of $\mathrm{La}_{2} \mathrm{Zr}_{2} \mathrm{O}_{7}$ pyrochlore. Phys. Rev. B66, 054108-1 $-054108-5$.

Loewen, E.P. \& León, S.B. (2001): Implications of recent developments in global climate change policy - a radical suggestion. Nuclear News 44, 23-25.

LuMPKIN, G.R. (2001): Alpha-decay damage and aqueous durability of actinide host phases in natural systems. $J$. Nucl. Mater. 289, 136-166.

SMith, K.L., GierÉ, R. \& Williams, C.T. (2004): The geochemical behavior of host phases for actinides and fission products in crystalline ceramic nuclear waste forms. In Energy, Waste and the Environment - a Geochemical Perspective (R. Gieré \& P. Stille, eds.). Geol. Soc., Spec. Publ. 236, 89-111.

Lutze, W. \& EwING, R.C., eds. (1988): Radioactive Waste Forms for the Future. North-Holland, Amsterdam, The Netherlands.

MARK, J.C. (1993): Explosive properties of reactor-grade plutonium. Science \& Global Security 4, 111-128.

National Commission on Energy Policy (2004): Ending the Energy Stalemate: A Bipartisan Strategy to Meet America's Energy Challenges. http://www.energycommission. org/ewebeditpro/items/O82F4682.pdf.

National Research Council (1994): Management and Disposition of Excess Weapons Plutonium. The National Academy Press, Washington, D.C.

(2001): Disposition of High-level Waste and Spent Nuclear Fuel, The Continuing Societal and Technical Challenges. The National Academy Press, Washington, D.C.

(2003): End Points for Spent Nuclear fuel and HighLevel Radioactive Waste in Russia and the United States. The National Academy Press, Washington, D.C.

Oversby, V.M., McPheeters, C.C., Degueldre, C. \& PARATTE, J.M. (1997): Control of civilian plutonium inventories using burning in a non-fertile fuel. J. Nucl. Mater. 245, 17-26.

Panero, W.R., Stixrude, L.P. \& Ewing, R.C. (2004): Firstprinciple calculation of defect-formation energies in $\mathrm{Y}_{2}(\mathrm{Ti}, \mathrm{Sn}, \mathrm{Zr})_{2} \mathrm{O}_{7}$-pyrochlore. Phys. Rev. B70, 054110-1 $-054110-11$.

Pigford, T.H. (1976): Environmental aspects of nuclear energy production. In Annual Review of Energy 1 (J.M. Hollander \& M.K. Simmons, eds.). Annual Reviews Inc., Palo Alto, California (515-559).

(1990): Actinide burning and waste disposal. Proc. First MIT Conf. on the Next Generation of Nuclear Power Technology, 8-19-8-53.

PuRTON, J.A. \& Allan, N.L. (2002): Displacement cascades in $\mathrm{Gd}_{2} \mathrm{Ti}_{2} \mathrm{O}_{7}$ and $\mathrm{Gd}_{2} \mathrm{Zr}_{2} \mathrm{O}_{7}$ : a molecular dynamics study. J. Mater. Chem. 12, 2923-2926. 
Raison, P.E., Haire, R.G., Sato, T. \& Ogawa, T. (1999): Fundamental and technological aspects of actinide oxide pyrochlores: relevance for immobilization matrices. In Scientific Basis for Nuclear Waste Management XXII (D.J. Wronkiewicz \& J.H. Lee, eds.). Mater. Res. Soc., Symp. Proc. 556, 3-10.

RevelLe, R. \& Suess, H.E. (1957): Carbon dioxide exchange between atmosphere and ocean and the question of an increase in $\mathrm{CO}_{2}$ during the past decades. Tellus 9, 18-27.

Sailor, W.C., Bodansky, D., Braun, C., Fetter, S. \& van DER ZWANN, B. (2000): A nuclear solution to climate change? Science 288, 1177-1178.

SARmiento, J.L. \& Gruber, N. (2002): Sinks for anthropogenic carbon. Physics Today 55, 30-36.

Schimel, D.S., House, J.I., Hibbard, K.A., Bousquet, P., Ciais, P., Peylin, P., Braswell, B.H., Apps, M.J., BaKer, D., Bondeau, A., Canadell, J., Churkina, G., Cramer, W., Denning, A.S., Field, C.B., Friedlingstein, P., Goodale, C., Heimann, M., Houghton, R.A., Melillo, J.M., Moore, B., III, Murdiyarso, D., Noble, I., Pacala, S.W., Prentice, I.C., Raupach, M.R., Rayner, P.J., Scholes, R.J., STEFFEN, W.L. \& WIRTH, C. (2001): Recent patterns and mechanisms of carbon exchange by terrestrial ecosystems. Nature 414, 169-172.

Sickafus, K.E., Minervini, L., Grimes, R.W., Valdez, J.A., Ishimaru, M., LI, F., McClellan, K.J. \& Hartmann, T. (2000): Radiation tolerance of complex oxides. Science 289, 748-751.

Stoll, W. (1998): What are the options for disposition of excess weapons plutonium? Mater. Res. Soc., Bull. 23, 6-16.

Subramanian, M.A., Aravamudan, G. \& Subba Rao, G.V. (1983): Oxide pyrochlores - a review. Prog. Solid State Chem. 15, 55-143.

SuESS, H.E. (1955): Radiocarbon concentration in modern wood. Science 122, 415-417.

Sutcliffe, W.G., Condit, R.H., MANSField, W.G., Myers, D.S., LAYTON, D.W. \& MuRPhY, P.W. (1995): A perspective on the dangers of plutonium. Center for Security and Technology Studies, Lawrence Livermore Laboratory, Rep. CSTS-48-95.

VON HIPPEL, F.N. (2001): Plutonium and reprocessing of spent nuclear fuel. Science 293, 2397-2398.

WANG, S.X., BegG, B.D., WANG, L.M., EwING, R.C., Weber, W.J. \& KuTTY, K.V.G. (1999b): Radiation stability of gadolinium zirconate: a waste form for plutonium disposition. J. Mater. Res. 14, 4470-4473.

WANG, L.M. \& EwING, R.C. (2001): Irradiationinduced amorphization: effects of temperature, ion mass, cascade size, and dose rate. Phys. Rev. B63, 024105024113.
\& KUTTY, K.V.G. (2000): Ion

irradiation of rare-earth- and yttrium-titanate-pyrochlores. Nucl. Instrum. Methods Phys. Res. B169, 135-140.

, WAS, G.S. \& LUMPKIN, G.R.

(1999a): Ion irradiation-induced phase transformation of pyrochlore and zirconolite. Nucl. Instr. Method Phys. Res. B148, 704-709.

Weber, W.J. (2000): Models and mechanisms of irradiation-induced amorphization in ceramics, Nucl. Instrum. Methods Phys. Res. B166, 98-106.

Ewing, R.C., Angell, C.A., Arnold, G.W., Cormack, A.N., Delaye, J.M., Griscom, D.L., HobBs, L.W., Navrotsky, A., Price, D.L., Stoneham, A.M. \& WEINBERG, M.C. (1997): Radiation effects in glasses used for immobilization of high-level waste and plutonium disposition. J. Mater. Res. 12, 1946-1978.

Catlow, C.R.A., Diaz de la Rubia, T., Hobbs, L.W., Kinoshita, C., Matzke, H., Motta, A.T. Nastasi, M., Salje, E.K.H., Vance, E.R. \& Zinkle, S.J. (1998): Radiation effects in crystalline ceramics for the immobilization of high-level nuclear waste and plutonium. J. Mater. Res. 13, 1434-1484.

WALD, J.W. \& MATZKE, H. (1985a): Self-radiation damage in actinide host phases for nuclear waste forms. Mater. Res. Soc.,Symp. Proc. 8, 679-686.

$\&$ (1985b): Self-radiation damage in $\mathrm{Gd}_{2} \mathrm{Ti}_{2} \mathrm{O}_{7}$. Mater. Lett. 3, 173-180.

$\&$ (1986): Effects of selfradiation damage in $\mathrm{Cm}$-doped $\mathrm{Gd}_{2} \mathrm{Ti}_{2} \mathrm{O}_{7}$ and $\mathrm{CaZrTi}_{2} \mathrm{O}_{7}$ J. Nucl. Mater. 138, 196-209.

WeInberg, A.M. (2000): Some necessary conditions for the rebirth of nuclear energy. Nuclear News 43, 47-48.

WigLEY, T.M.L. (1997): Implications of recent $\mathrm{CO}_{2}$ emission - limitation proposals for stabilization of atmospheric concentrations. Science 390, 267-270.

Williams, R.H. \& Feiveson, H.A. (1990): How to expand nuclear power without proliferation. Bull. Atomic Scientists 46, 1-8.

WILliford, R.E. \& WeBER, W.J. (2001): Computer simulation of $\mathrm{Pu}^{3+}$ and $\mathrm{Pu}^{4+}$ substitutions in gadolinium zirconate. $J$. Nucl. Mater. 299, 140-147.

Wuensch, B.J. \& EBerman, K.W. (2000): Order-disorder phenomena in $\mathrm{A}_{2} \mathrm{~B}_{2} \mathrm{O}_{7}$ pyrochlore oxides. J. Metals $-J$. Mining, Metall., Mater. Soc. 52, 19-21.

Received February 25, 2004, revised manuscript accepted July 12, 2005. 